\title{
ESPAÇO ABERTO \\ Trabalho, educação e perspectiva histórica da classe trabalhadora: continuando o debate
}

\author{
PAULO SERGIO TUMOLO \\ Universidade Federal de Santa Catarina
}

Em meados de 2009, veio a público um artigo de Gaudêncio Frigotto na Revista Brasileira de Educaşão n. 40 intitulado "A polissemia da categoria trabalho e a batalha das ideias nas sociedades de classe" (Frigotto, 2009). Produzido originalmente para ser apresentado como trabalho encomendado no GT Trabalho e Educação, durante a 31 $1^{\text {a }}$ Reunião Anual da ANPEd, o texto propõe-se a estimular o debate sobre a relação trabalho, classe social e educação, e o faz por meio da abordagem de dois pontos inter-relacionados. O primeiro diz respeito ao tema da polissemia da categoria trabalho e o segundo trata da relação entre a compreensão imanente e a historicidade dos fundamentos do pensamento de Marx, por intermédio de um diálogo crítico, primeiramente, com o livro de Sergio Lessa Trabalho e proletariado no capitalismo contemporâneo (Lessa, 2007) e, secundariamente, com um artigo de minha autoria intitulado "O significado do trabalho no capitalismo e o trabalho como princípio educativo: ensaio de análise crítica” (Tumolo, 2003a).

Para atingir seus objetivos, o autor constrói uma primeira parte na qual busca "sinalizar que a polissemia da categoria trabalho resulta de uma construção social e, em nossa sociedade, com o sentido de dominação de classe" (Frigotto, 2009, p. 170). Para ele, "o grande desafio é apreender, no tecido social do senso comum, das religiões e das ideias do pensamento e da ciência positivista e pragmática dominante, 
qual o mosaico de sentidos que assume o trabalho" (idem, ibidem). Frigotto encara o desafio apresentando e analisando as questões e temas mais candentes - com destaque para as categorias de trabalho, emprego e classe social -, valendo-se de um leque dos mais importantes autores que se vêm debruçando sobre tais temáticas.

Com base nos elementos teóricos apresentados na primeira parte, o autor dedica-se, no restante de seu texto, a estabelecer uma interlocução crítica com o livro de Lessa e, em seguida, com meu artigo.

Frigotto oferece nesse texto, a exemplo do que se pode observar em toda sua produção teórica e também em suas intervenções, uma inestimável contribuição não apenas para o GT Trabalho e Educação da ANPEd, mas também para o campo da educação e para várias áreas das ciências humanas. Penso, como ele, que a polêmica sobre o tema do trabalho é de vital relevância porque, como afirma em seu texto, "aprendemos e ensinamos uns aos outros". Além da primorosa análise sobre a polissemia da categoria trabalho, o autor buscou, no diálogo crítico com os textos dos dois autores supracitados, indicar suas respectivas contribuições para o debate, mas, principalmente, apontar os possíveis limites, insuficiências e equívocos. Daí a importância de seu artigo.

O texto que ora apresento tem o mesmo propósito, vale dizer, dar sequência à discussão desse intrincado e controverso assunto, não apenas visando contribuir para oxigenar a produção do conhecimento, mas, sobretudo, porque isso nos ajuda a construir ferramentas teóricas mais poderosas para nossa luta política pela emancipação humana, que é nosso objetivo comum.

Dada a excelência de sua apreciação, parece-me desnecessário fazer comentários relativos à primeira parte do texto, o que me conduz para a segunda parte. Lamentavelmente, não terei condições de entrar no debate que Frigotto estabeleceu com Lessa porque isso extrapolaria os limites deste artigo. Dessa forma, pretendo concentrar minhas atenções nas ponderações críticas que Frigotto fez em relação a meu texto.

Antes de adentrar propriamente nas questões, creio ser necessário fazer um esclarecimento. $\mathrm{O}$ artigo, alvo da análise crítica de Frigotto, foi publicado primeiramente na revista eletrônica Trabalho Necessário, referência que ele utiliza em seu texto. Porém, o artigo foi publicado na forma impressa dois anos depois na revista Educação E̋ Sociedade n. 90, com algumas alterações em relação à primeira versão, fruto de algumas releituras que fiz e de algumas sugestões de pesquisadores que o leram, tendo recebido, então, o título de "O trabalho na forma social do capital e o trabalho como princípio educativo: uma articulação possível?”. Ou seja, na revista Educação E̋ Sociedade o artigo aparece mais amadurecido, e supera ou resolve alguns problemas que Frigotto indica em seu texto, como poderemos verificar. As alterações foram feitas na introdução e nas considerações finais, justamente os segmentos que foram foco de suas críticas. Por isso, tentarei fazer o diálogo com ele valendo-me das duas versões.

Num primeiro momento, farei uma avaliação crítica das críticas de Frigotto a meu texto, e, em seguida, discutirei outras questões concernentes à relação entre trabalho, educação e estratégia de superação do capitalismo. 


\section{A CRÍTICA DAS CRÍTICAS}

Resumidamente, a argumentação crítica de Frigotto a meu artigo dirige-se a dois eixos de questões: as preliminares e as que considero centrais.

\section{As questões preliminares}

Iniciarei meu diálogo com o texto de Frigotto tratando de três questões preliminares, que aparecem enumeradas na sequência.

1. No início da primeira versão de meu texto, com o objetivo de introduzir o leitor no assunto - o significado do trabalho no capitalismo e o trabalho como princípio educativo -, menciono, em nota de rodapé, um conjunto de autores que, de uma forma ou de outra, abordaram o tema e, na impossibilidade de realizar uma discussão teórica com eles, faço uma citação de Saviani que, no meu entender, poderia sintetizar o cerne da compreensão daquele bloco de autores acerca do trabalho. A esse respeito, Frigotto assim se manifesta:

Mesmo que o autor [Tumolo] assuma tratar-se de um texto introdutório, não pode cometer a impropriedade de pinçar uma citação de uma entrevista numa revista, sendo que na bibliografia cita mais três obras de Saviani, nem partir da suposição de que os demais 12 autores e suas 19 obras referidas estejam contemplados em tal citação. $\mathrm{O}$ mais estranho e paradoxal é que a citação não trata diretamente do trabalho como princípio educativo, mas da relação da estruturação do sistema educacional e o trabalho como produção da existência humana. Do mesmo modo, a maior parte das obras referidas não trata do trabalho como princípio educativo. (Frigotto, 2009, p. 188)

O autor tem razão parcial com relação ao conteúdo da última frase; tanto é verdade que, na segunda versão, organizei melhor a exposição da produção bibliográfica trazendo-a para o corpo do texto, de maneira que apresentasse os autores que trataram diretamente do tema do trabalho como princípio educativo e aqueles que o fizeram de forma indireta, resolvendo, assim, o problema apontado por Frigotto. Contudo, os outros aspectos devem ser mais bem examinados.

Como se sabe, a produção de um artigo para ser publicado em uma revista requer uma série de critérios, inclusive limite de caracteres. De outra parte, há de se reconhecer que a discussão sobre o trabalbo e o trabalho como princípio educativo tem se mostrado inesgotável e tem demandado uma enorme produção teórica, principalmente dentro da seara marxista. Os dois assuntos, em sua inter-relação, perseguem-me desde o início de meus estudos mais sistemáticos. No artigo que elaborei, alvo desta discussão, não poderia apresentar uma análise da contribuição teórica dos autores que vêm dedicando-se a estudar a questão do trabalho como princípio educativo, pela simples razão de que isso tomaria todo o espaço permitido 
para o texto. Dada a complexidade do tema, penso que isso exigiria muito mais do que a elaboração de um artigo. Tendo de escolher o foco da discussão e considerando já existir razoável produção de textos que tratam do trabalho como princípio educativo, e também que havia um limite objetivo no tamanho do texto, decidi centrar minha análise no tema do trabalho, tal como vem sendo tomado como princípio educativo, ou seja, o trabalho produtor de valores de uso. Por isso, na introdução do artigo, para inserir o leitor no assunto, faço um breve panorama da discussão sobre o trabalho como princípio educativo e apresento uma lista dos principais autores que se vêm debruçando sobre o tema; em seguida, remeto-me para o alvo principal: a questão do trabalho. Na primeira versão do artigo, esclareço que "escapa aos propósitos deste texto apresentar as abordagens realizadas pelos numerosos autores que se ocuparam do assunto" (Tumolo, 2003a, p. 1) e indico, em nota de rodapé, outro artigo de minha autoria (Tumolo, 1996), no qual se pode encontrar um estudo introdutório desse tipo. $\mathrm{Na}$ segunda versão, depois de apresentar um elenco de autores e obras que trataram do tema, afirmo:

Como se pode inferir, seja pelo volume de obras, ou pela densidade e qualidade da produção, a discussão do trabalho como princípio educativo é praticamente inesgotável e permite os mais variados recortes e enfoques. Dessa maneira, como é impossível, dados os limites de um artigo, abarcar o assunto em todos seus aspectos, impõe-se uma escolha, qual seja, buscarei examinar, mesmo que de forma introdutória e ensaística, o significado do trabalho no modo capitalista de produção, à luz da contribuição teórica oferecida por Marx, sobretudo em O Capital e, com essa base, levantar algumas questões referentes ao trabalho como princípio educativo. (Tumolo, 2005, p. 240-241)

Como meu objetivo principal era fazer um exame da compreensão do trabalho que fundamenta a proposta do trabalho como princípio educativo, elegi uma citação de Saviani que me pareceu mais adequada, porque resumia ou sintetizava tal compreensão entre o conjunto de autores:

Na verdade, todo sistema educacional se estrutura a partir da questão do trabalho, pois o trabalho é a base da existência humana, e os homens se caracterizam como tais na medida em que produzem sua própria existência, a partir de suas necessidades. Trabalhar é agir sobre a natureza, agir sobre a realidade, transformando-a em função dos objetivos, das necessidades humanas. A sociedade se estrutura em função da maneira pela qual se organiza o processo de produção da existência humana, o processo de trabalho. (Saviani, 1986, p. 14)

Na segunda versão, ao término da citação, inseri uma nota de rodapé nos seguintes termos: 
Num artigo posterior, o mesmo autor confirma: "em suma, pode-se afirmar que o trabalho foi, é e continuará sendo o princípio educativo do sistema de ensino em seu conjunto. Determinou o seu surgimento sobre a base da escola primária, o seu desenvolvimento e diversificação e tende a determinar, no contexto das tecnologias avançadas, a sua unificação" [Saviani, 1994, p. 161, grifo meu]. (Tumolo, 2005, p. 257, grifo meu)

$\mathrm{O}$ artigo de Saviani a que se refere essa citação foi intitulado "O trabalho como princípio educativo frente às novas tecnologias" (Saviani, 1994). Nele, o autor faz um estudo da relação entre educação e trabalho passando pelos diversos modos de produção e concentrando-se no capitalismo. Em nenhum momento desse artigo, Saviani apresenta uma definição do que seja trabalho como princípio educativo, mas é possível apreender do texto que seu entendimento se refere à relação entre sistema educacional (escolar) e trabalho, e que sua compreensão deste último é de trabalho que produz valores de uso.

Um cotejamento entre esse artigo de Saviani e o conteúdo da entrevista citada em meu texto pode comprovar que, na entrevista, ele estava referindo-se diretamente ao trabalho como princípio educativo, ao contrário do que afirmou Frigotto, e que sua acepção de trabalho é a de produtor de valores de uso.

Da mesma forma, uma investigação da produção dos autores que se vêm debruçando sobre o tema do trabalho como princípio educativo certamente constataria que há um consenso basilar entre eles: o pressuposto - explícito ou implícito - segundo o qual a concepção de trabalho que embasa a proposta do trabalho como princípio educativo é a do trabalho produtor de valores de uso. Aliás, Frigotto não foge à regra. No mesmo artigo aqui apreciado, ele explicita sua compreensão do trabalho que considera princípio educativo.

Da leitura que faço do trabalho como princípio educativo em Marx, ele não está ligado diretamente a método pedagógico nem à escola, mas a um processo de socialização e de internalização de caráter e personalidade solidários, fundamental no processo de superação [grifado no original] do sistema do capital e da ideologia das sociedades de classe que cindem o gênero humano. Não se trata de uma solidariedade psicologizante ou moralizante. Ao contrário, ela se fundamenta no fato de que todo ser humano, como ser da natureza, tem o imperativo de, pelo trabalho, buscar os meios de sua reprodução - primeiramente biológica, e na base desse imperativo da necessidade criar [sic!] e dilatar o mundo efetivamente livre. Socializar ou educar-se de que o trabalho que produz valores de uso [grifo meu] é tarefa de todos, é uma perspectiva constituinte da sociedade sem classes. (Frigotto, 2009, p. 189)

$\mathrm{Na}$ sequência, o autor desenvolve sua explicação e confirma a compreensão anterior: 
Por ser o trabalho (mediação de primeira ordem) o que possibilita que o ser humano produza-se e reproduza-se, e por isso, na metáfora de Marx, antediluviano [grifado no original], e não o trabalho escravo, servil e o trabalho alienado sob o capital (mediações de segunda ordem), a internalização, desde a infância, do princípio do trabalho produtor de valores de uso é fundamental. (idem, ibidem, grifos meus)

Aqui me parece pertinente fazer uma observação. Embora a concepção de trabalho seja coincidente, Frigotto expressa, nesse texto, uma compreensão de princípio educativo distinta daquela apresentada por Saviani, já que o entendimento deste último aponta na direção da relação entre trabalho e educação primordialmente escolar.

Uma abordagem panorâmica das obras dos autores que vêm examinando a questão do trabalho como princípio educativo permitiria chegar a duas conclusões referentes aos aspectos até aqui sublinhados: 1 . não há consenso quanto ao entendimento do que seja princípio educativo e 2. diferentemente, a concepção de trabalho que defendem como princípio educativo é consensual, ou seja, é a de trabalho produtor de valores de uso, exatamente como aparece na citação de Saviani utilizada no início de meu texto. Independentemente dos diferentes significados que possam ser atribuídos a princípio educativo, o que me interessava discutir em meu texto era a concepção de trabalho que tem fundamentado a proposição do trabalho como princípio educativo, não apenas porque ela é consensual, mas, sobretudo, porque é determinante.

Portanto, ao contrário do que assevera Frigotto, não cometi nenhuma impropriedade ao lançar mão da citação de Saviani, uma vez que, nela, o autor apresenta a compreensão que tem de trabalho como princípio educativo. Dessa forma, portanto, está referindo-se diretamente ao trabalho como princípio educativo e, como afirmei em meu texto, de fato sintetiza a concepção de trabalho presente nos autores que defendem a referida proposta, inclusive Frigotto, que era o tema que eu pretendia privilegiar em minha análise. Na verdade, já que a concepção de trabalho é comum, poderia ter me valido de outras citações de Saviani e de outros autores, inclusive de Frigotto, o que não faria nenhuma diferença para a discussão que pretendia fazer em meu texto. Sem dúvida, as duas citações de Frigotto sobre o trabalho como princípio educativo reproduzidas anteriormente teriam sido mais adequadas do que as de Saviani, desde que tivessem sido publicadas antes da produção de meu texto.

Da mesma forma, também não procede a afirmação de Frigotto segundo a qual eu tenha partido da suposição de que os outros autores e obras apresentados em meu texto estivessem contemplados na citação de Saviani. O que afirmei foi que a citação sintetizava a concepção de trabalho presente neles quando tratam do trabalho como princípio educativo, o que é muito diferente. 
2. Em algumas partes de seu artigo, Frigotto fez uma crítica a uma afirmação posta em meu texto de que o trabalho como princípio educativo seria um lema que careceria de precisão e consistência teóricas, e, relembrando a produção teórica acerca do tema, inclusive por intelectuais ligados ao Movimento dos Trabalhadores Rurais Sem Terra (MST), considera-a uma "generalidade e uma impropriedade" (idem, p. 188).

Sobre isso, parece-me necessário fazer alguns esclarecimentos. Na primeira versão de meu texto, quando afirmo que "se trata apenas de um lema, que carece de precisão e consistência teóricas”, não estava referindo-me à contribuição teórica de vários conhecidos autores que Frigotto cita e que têm sido referências para o MST - o que teria sido uma leviandade -, e sim às "mais variadas e desencontradas concepções" (Tumolo, 2003a, p. 1) que poderiam ser encontradas no seio da Central Única dos Trabalhadores (CUT) e do MST sobre o trabalho como princípio educativo. Eu mesmo pude comprovar isso no caso da CUT, que foi meu objeto de investigação no doutorado, e, no caso do MST, pela proximidade e relação que tenho com militantes desse movimento. ${ }^{1}$ Para esclarecer o sentido que queria atribuir à afirmação, dei um exemplo real na nota de rodapé n. 3 , que foi ignorada por Frigotto:

$\mathrm{O}$ autor deste texto [Tumolo] foi convidado para fazer uma conferência e um debate sobre "O trabalho como princípio educativo" numa das escolas da CUT, em 1999. Depois da análise e aberto o debate, um dos educadores da escola afirmou que pensava que trabalho como "principio" educativo significava que o educador deveria "iniciar" sua atividade educativa, com um público de trabalhadores, pedindo que estes falassem acerca de sua realidade de "trabalho". (idem, p. 10, grifos meus)

Como se pode ver pelo exemplo anterior, a preocupação que manifestei em meu artigo era pertinente. Se Frigotto demonstrou, em seu texto, que há uma polissemia da categoria trabalho, ela é muito mais agravada quando se trata do trabalho como princípio educativo, o que facilita a proliferação de compreensões variadas e convenientes. Ademais, como já foi observado, mesmo entre os estudiosos da matéria não há coincidência quanto à compreensão do princípio educativo do trabalho. Por esses motivos, a crítica de Frigotto a esse quesito de meu texto revela-se inapropriada, já que eu estava referindo-me a interpretações problemáticas e usos atribuídos ao trabalho como princípio educativo, e não à contribuição teórica dos autores sobre o assunto. De todo modo, como não tinha espaço para apresentar os elementos comprobatórios e como não era a questão central que queria apreciar, e

1 Lamentavelmente, não tenho espaço, neste texto, para desenvolver esse assunto. 
também para não causar confusões, a exemplo do que fez Frigotto, decidi retirar a afirmação "se trata apenas de um lema, que carece de precisão e consistência teóricas" no artigo publicado na revista Educação E̊ Sociedade e refazer o texto. Portanto, o assunto já estava definitivamente resolvido nessa última versão, publicada quatro anos antes do artigo de Frigotto.

3. Por fim, creio que seja necessário prestar ainda uma informação. A frase “o trabalho não pode ser considerado como princípio educativo de uma estratégia político-educativa que tenha como horizonte a transformação revolucionária da ordem do capital", bem como outras frases que estão no final do texto e que foram mencionadas por Frigotto, aparecem na primeira versão como afirmações, mas na segunda estão como indagações. Tal alteração foi feita por duas razões: para que o leitor tire, ele próprio, suas conclusões a partir do conjunto de argumentos apresentados e, já que o texto termina com várias perguntas e não respostas, deixa claramente demarcado seu caráter de abertura, vale dizer, indica que a discussão, longe de estar encerrada, demanda continuidade.

\section{As questões centrais}

Entre as várias questões que mereceram a avaliação crítica de Frigotto, duas delas são centrais, e aparecem organicamente articuladas em seu texto. A primeira diz respeito à historicidade, à ideia advogada por Frigotto de que devemos "Pensar com Marx para além de Marx”, e à questão da práxis política, e a segunda refere-se aos temas da contradição, da antinomia e do trabalho alienado. Buscarei avaliar cada uma delas a seguir.

\section{“PENSAR COM MARX PARA ALÉM DE MARX” E AS QUESTÕES DA HISTORICIDADE E DA PRÁXIS POLÍTICA}

Partindo do pressuposto de que o livro de Lessa e meu artigo são resultado de uma abordagem imanente de obras de Marx, Frigotto afirma que "o ponto crucial a ser debatido é a passagem da compreensão imanente do trabalho, da classe proletária e do sujeito revolucionário, para a análise ou julgamento de trabalhos que se centram, há décadas, em desenvolver pesquisa histórico-empírica e que pensam com Marx para além de Marx" (idem, p. 171, grifo do original).

Mesmo reconhecendo que há uma especificidade e uma natureza diversa nos textos dos dois autores, Frigotto pretendeu demonstrar que eles

[...] podem estar incorrendo nessa impropriedade. Isso pode ter como consequência, ainda que não intencional, em nome da imanência e da ortodoxia, por um lado, congelar a saturação histórica das categorias e conceitos e, com isso, o 
legado fundamental de Marx de perquirir a relação do estrutural e conjuntural no tempo e no espaço, nas mediações e contradições singulares, particulares e universais da realidade que queremos compreender; e, por outro, conduzir ao imobilismo no plano da práxis, ponto nodal da luta de classes para a superação das relações sociais capitalistas. (idem, ibidem, grifo do original)

Depois de fazer uma apreciação dos textos dos dois autores com os quais dialogou criticamente, Frigotto confirmou a hipótese levantada inicialmente.

O que se buscou evidenciar é que Lessa e Tumolo fazem suas análises dentro da perspectiva imanente e heurística dos textos de Marx, tomando sobretudo o Livro I de $O$ capital. Uma abordagem não só sustentável como importante na compreensão dos fundamentos do pensamento de Marx e de outros pensadores clássicos. Trata-se de abordagem tão importante quanto a abordagem que analisa as formações históricas. Como adverte Thompson, confusões geralmente surgem quando nos deslocamos de uma acepção para outra.

Nos textos de Lessa e Tumolo aqui analisados, o que busquei evidenciar é que este deslocamento se efetivou. Dar um tratamento imanente e heurístico a trabalhos de natureza histórica os conduziu a não tratar a contradição no sentido da materialidade do processo histórico em que negatividade e positividade são indissociáveis. (idem, p. 191)

Frigotto entende que meu texto, bem como o livro de Lessa, apresentam uma abordagem imanente e heurística dos textos de Marx, com destaque para o livro I de O Capital. Embora ele reconheça a importância de tal tratamento, sua tese é a de que tanto eu quanto Lessa não demos o salto dessa abordagem para uma análise histórico-concreta, ou, se se quiser, para uma análise da "relação do estrutural e conjuntural no tempo e no espaço, nas mediações e contradições singulares, particulares e universais da realidade que queremos compreender"; em outras palavras, que nós "congelamos a saturação histórica das categorias e conceitos", ou seja, não alcançamos a historicidade, e, por decorrência, a compreensão do real como contradição. No caso específico de meu texto, porque toda análise, segundo Frigotto, teria se baseado na compreensão de trabalbo alienado, e, dessa forma, teria considerado apenas o aspecto de negatividade do trabalho e não a contradição entre negatividade e positividade (cf. Frigotto, 2009, p. 171, 192).

Essa abordagem realizada por Lessa e por mim traria duas consequências. Em primeiro lugar, já que, segundo Frigotto, não fizemos uma análise histórica e operamos dentro de uma lógica antinômica, nossos textos incorreram na impropriedade de fazer crítica a autores que pensam com Marx para além de Marx, ou seja, que buscaram realizar trabalhos de natureza histórico-empírica e que se pautaram pela contradição. Em segundo lugar, essa posição teórica conduziria ao imobilismo no plano da práxis e, por isso, a um "beco sem saída". 
Uma vez apresentados os elementos que considerou comuns no livro de Lessa e em meu texto, Frigotto analisa especificamente cada um deles. Como já havia sinalizado, vou dedicar-me à apreciação feita sobre meu artigo. Começarei pela questão da reivindicação feita por Frigotto de se pensar com Marx para além de Marx. Para tanto, parece-me necessário reconstituir, brevemente, o itinerário investigativo desse autor clássico, que foi, em parte, relatado por ele próprio no "Prefácio de Para a crítica da economia política" (Marx, 1974).

Em 1842, quando era redator do jornal Gazeta Renana, Marx viu-se "pela primeira vez em apuros por ter que tomar parte na discussão sobre os chamados interesses materiais" (Marx, 1974, p. 134), entre outros, os problemas do "roubo" de madeira, utilizada como lenha, que representava cinco sextos de todos os processos legais na Prússia. Isso o impeliu a redigir um artigo que foi publicado no jornal, no qual questionava a propriedade privada como uma forma de roubo. A partir dessa "situação concreta", Marx desenvolveu a crítica à filosofia do direito de Hegel - é o ser social e, portanto, a forma social de produzir sua existência que determinam o direito e o Estado e não o inverso -, o que o conduziu à necessidade de desvendar os fundamentos do modo capitalista de produção, que se vinham constituindo como objeto de investigação da economia política clássica. Por esse motivo, a partir de 1844, Marx mergulhou fundo no estudo dessa matéria e foi construindo uma sólida crítica à economia política clássica, incorporando muitos de seus elementos teóricos, e, ao mesmo tempo, superando-a, tarefa que só se tornou possível graças à apreensão que havia feito da dialética de Hegel, "invertendo-a" como dialética materialista, ou seja, colocando-a com "os pés e a cabeça em seus devidos lugares”. Como se sabe, o resultado disso foi a produção de sua principal obra teórico-política - O Capital-, na qual conseguiu dissecar e desvelar as leis que regem o movimento contraditório do capital, como forma histórica de produção da existência do ser social. A apreensão do capital permitiu-lhe compreender, agora num patamar qualitativamente mais elevado, as questões relacionadas a seu ponto de partida, o "roubo" de lenha etc., e, na sequência de sua trajetória intelectual, forneceu-lhe os fundamentos para que pudesse fazer "análises concretas de realidades concretas", como comprova, entre outros textos, a trilogia que produziu sobre três acontecimentos históricos ocorridos na França - As lutas de classe na França de 1848 a 1850 (Marx, s.d. a), O dezoito brumário de Luiz Bonaparte (Marx, s.d. b) e A guerra civil na França (Marx, s.d. c).

O conteúdo teórico produzido em O Capital também ofereceu, a Marx e a Engels, o suporte teórico necessário para avaliar e criticar as diversas estratégias de ação política desenhadas pelas variadas correntes político-ideológicas do movimento operário daquela época, desde as traçadas pelos "socialistas utópicos”, passando por aquelas dos anarquistas até as estratégias que foram discutidas no âmbito da Associação Internacional dos Trabalhadores e de alguns partidos operários daquele 
período. Exemplos disso são os textos Do socialismo utópico ao socialismo científico (Engels, 1988); A miséria da filosofia (Marx, 1989), no qual Marx polemiza com Proudhon; Salário, preço e lucro (Marx, 1988), em que discute com o líder operário J. Weston; e "Crítica ao programa de Gotha" (Marx, 1975), no qual faz uma apreciação crítica da estratégia proposta pelo Partido Operário Social-Democrata alemão. Ao mesmo tempo, o arcabouço teórico construído em O Capital forneceu aos dois pensadores-militantes uma sólida base para elaborar e apresentar suas propostas estratégicas. O Manifesto do Partido Comunista (Marx; Engels, 1998) é o primeiro esboço desse intento e Mensagem do comitê central à Liga dos Comunistas (Marx \& Engels, s.d.) é expressão viva da preocupação dos dois autores com esse tema. As principais teses contidas neste último texto foram retomadas por Lenin e contribuíram para a elaboração, entre outros, de seus textos Sobre as tarefas do proletariado na presente revolução (Lenin, 1982), conhecido como Teses de abril, e $O$ Estado e a revolução (Lenin, 1987), instrumentos decisivos para a vitória da revolução de outubro de 1917.

O empreendimento teórico realizado em O Capital criou, portanto, o fundamento necessário que propiciou três desdobramentos: "análise concreta de realidades concretas", a crítica a estratégias políticas que se mostraram equivocadas, porque careciam de fundamentos, e a elaboração de propostas de estratégias revolucionárias com vistas à superação do modo capitalista de produção. Esses três fatores estão organicamente articulados entre si, uma vez que o último implica o segundo, que, por sua vez, implica o primeiro, e todos eles estão em total dependência da análise dos fundamentos do capital. Isso quer dizer que a elaboração de propostas de estratégias revolucionárias que tenham alguma chance de êxito pressupõe tanto "análises concretas de realidades concretas" quanto a crítica a estratégias equivocadas, porque infundadas e, sobretudo, pressupõe uma apreensão das leis que regem o movimento contraditório do capital, o que exige o método dialético materialista, já que capital é contradição em processo e, por isso, é necessário captar o "movimento do movimento em movimento".

Ocorre que "análises concretas de realidades concretas" insuficientes ou equivocadas podem provocar, e de fato têm produzido, a elaboração e implementação de estratégias insuficientes ou equivocadas ao longo da história do movimento da classe trabalhadora, e o século XX foi pródigo em exemplos, alguns deles trágicos. ${ }^{2}$

2 Talvez o mais significativo exemplo tenha sido a estratégia de ação política adotada pela social-democracia alemã a partir da década de 1910 e a consequente derrota da revolução alemã no início dos anos 1920 e o assassinato de Rosa Luxemburgo. No caso brasileiro, poderia ser mencionada a estratégia do Partido Comunista Brasileiro (PCB) a partir da segunda metade dos anos 1950 e sua posição perante o golpe burguês-militar de 1964 e a ditadura militar. 
Dessa forma, a superação do sistema do capital - que é o objetivo pleiteado por Frigotto, por Lessa e por mim - é apenas uma possibilidade histórica. Vários fatores devem concorrer para transformar essa possibilidade em realidade, por intermédio de um processo revolucionário - as chamadas condições objetivas e subjetivas, incluídas aí a situação, posição e organização da classe revolucionária, a correlação de forças no âmbito da luta de classes, a elaboração e implementação de uma estratégia revolucionária e, entre outros, o papel da teoria revolucionária. Sobre este aspecto, sabemos que, embora seja condição insuficiente, o conhecimento da realidade é diretamente proporcional à possibilidade de sucesso do empreendimento revolucionário, ou seja, quanto mais e melhor conhecemos a realidade, maiores serão suas chances e vice-versa.

A apreensão das leis que regem o movimento contraditório do capital é, portanto, condição sine qua non e, por isso, o "ponto de partida", tanto para fazer "análises concretas de realidades concretas", como para a elaboração de propostas de estratégias revolucionárias que tenham alguma possibilidade de êxito. Como Marx nos deixou um extraordinário legado teórico a esse respeito em O Capital, o estudo sistemático dessa obra é condição imprescindível para a realização de "análises concretas de realidades concretas" contemporâneas, ou seja, para a compreensão do capitalismo atual e de suas diversas formações sócio-históricas, como é o caso da América Latina ou, especificamente, do Brasil, e, principalmente, para a elaboração de propostas de estratégias revolucionárias que tenham alguma chance de sucesso, conjuntamente com a crítica a propostas estratégicas que possam ser limitadas ou equivocadas.

Por tudo isso, estou de acordo com a frase reivindicada por Frigotto: Pensar com Marx para além de Marx. A leitura da obra de Marx com um fim em si mesma não me parece apenas uma postura antimarxista, senão também algo sem nenhum sentido para qualquer um que se reivindica marxista. Já que Marx não poderia ter feito uma "análise concreta de realidades concretas" do século XXI e, portanto, proposto estratégias revolucionárias para a situação atual, essas são as principais tarefas para os marxistas hodiernamente. Porém insisto: para mim, pensar com Marx para além de Marx implica, juntamente com o exercício do método, um estudo profundo e sistemático de sua obra e, sobretudo, de O Capital, pelas razões políticas já apresentadas, ou seja, porque é condição necessária para termos alguma chance de superação do sistema sócio-metabólico do capital.

Como se viu antes, Frigotto afirma que apresento uma abordagem imanente e heurística de obras de Marx. Em meu texto, não reivindico uma leitura imanente, diferentemente do que fez Lessa em seu livro, ${ }^{3}$ e muito menos heurística. Prefiro

3 De fato, Lessa explicita a necessidade de fazer uma leitura imanente do livro I de $O$ Capital. Esse procedimento adquire tal importância em sua análise que o impeliu a 
entendê-la como exercício mesmo do método. Senão, vejamos. Nas duas versões de meu texto, o ponto de partida é o concreto aparente, ou seja, no caso específico da discussão que queria fazer, a compreensão corrente do trabalho como princípio educativo. A partir daí, busco traçar, a despeito de todos os limites, um caminho analítico para compreender o trabalho na forma social do capital, com o intuito de atingir o concreto pensado. Ora, o concreto pensado não é outra coisa senão o capital, síntese de múltiplas determinações e contradições. Uma vez chegado a este ponto, o da universalidade, faço o caminho de volta para apreciar o trabalho como princípio educativo. Contudo, o retorno não ocorre no mesmo plano da ida, mas num patamar qualitativamente superior, ou seja, o entendimento do trabalho como uma "rica totalidade de determinações e relações diversas” (Marx, 1974, p. 122). O exercício do método foi o que me forneceu o aporte necessário para questionar os limites e insuficiências da compreensão corrente do trabalho como princípio educativo. Porém, não foi necessário que eu tivesse de fazer toda a investigação para desvendar o capital em sua universalidade, porque Marx já a havia realizado, e seus resultados foram expostos em sua principal obra, O Capital. Por isso, parece-me que a compreensão dos fenômenos sociais produzidos na forma social do capital supõe a apreensão do capital e esta, por sua vez, pressupõe a leitura e compreensão de O Capital de Marx.

A discussão feita anteriormente fornece os elementos teórico-políticos para que se possa fazer uma avaliação da afirmação que Frigotto fez em seu artigo de que minha análise, de acordo com a abordagem e a posição teórica ali desenvolvidas, conduziria ao imobilismo no plano da práxis, e, portanto, a um "beco sem saída" (Frigotto, 2009, p. 192).

Como já foi mencionado, uma proposta de ação política, seja estratégica ou tática, é sempre, consciente ou inconscientemente, derivada de uma determinada leitura da realidade. Se é possível fazer mais do que uma leitura da realidade, isso resulta, por conseguinte, na formulação de mais de uma proposta de ação política, ou, em outras palavras, as propostas de ação política poderão ser tantas quantas forem as possibilidades de leituras da realidade. Por isso, leituras diferentes da realidade não conduzem ao imobilismo, mas sim a formulações de estratégias e táticas distintas, mais corretas ou mais equivocadas. O grau de acerto ou equívoco das análises e de suas respectivas propostas de ação política é conferido pela história, que é, em última instância, o critério de verdade.

Dessa forma, o questionamento a determinada análise e a sua correspondente formulação estratégica e tática não conduz ao imobilismo, a não ser que se

abrir, no início de seu livro, uma seção para apresentar sua compreensão a esse respeito, bem como as razões que o levaram a adotá-lo (Lessa, 2007, p. 10 e ss.). Parece-me que o entendimento de leitura imanente em Lessa tem diferenças em relação àquele apontado por Frigotto, já que para o primeiro a leitura imanente pressupõe a historicidade. 
entenda que existe apenas uma única proposta de estratégia de superação da ordem capitalista, derivada de uma única leitura da realidade. $\mathrm{O}$ argumento de Frigotto em relação a meu texto só teria validade por esse mesmo pressuposto: de que existe uma única leitura da realidade, e, por conseguinte, uma única proposta de ação política. Se esse é o entendimento, então, apenas para dar alguns exemplos, a análise que Marx desenvolveu na Crítica ao programa de Gotha (Marx, 1975), a discussão que Engels apresentou em seu Do socialismo utópico ao socialismo científico (Engels, 1988), assim como a crítica que Lênin fez a Kautsky em O Estado e a revolução (Lenin, 1987) poderiam ser interpretadas como análises que levariam ao imobilismo e a um "beco sem saída". Ora, a polêmica advinda de análises distintas da realidade e a disputa de propostas políticas diferenciadas, derivadas daquelas, foram a marca distintiva das mais importantes organizações proletárias de corte não stalinista e ofereceram o oxigênio necessário para sua existência. Exemplo dessa prática pode ser encontrado na trajetória pré-revolucionária dos bolcheviques, característica que foi, em grande medida, responsável pelo êxito revolucionário de Outubro de 1917, e que foi definitivamente eliminada com o advento do stalinismo.

Como, na atualidade, continua sendo possível fazer leituras distintas do real, mesmo que baseadas num mesmo referencial teórico, que resultam em propostas diferentes de ação política, mais corretas ou mais equivocadas, então a afirmação de Frigotto de que minha análise conduziria ao imobilismo e a um "beco sem saída" é improcedente, mesmo sob a suposição de que ela estivesse equivocada. Cai por terra, assim, mais um elemento de sua crítica a meu texto.

Outro argumento de Frigotto, relacionado aos anteriores, é o de que a análise que desenvolvi em meu artigo não atingiu a historicidade. Grosso modo, sua explicação é a de que minha análise não considerou a contradição - tema que será apreciado no próximo segmento - e, como se circunscreveu à leitura (imanente) de $O$ Capital, não desceu ao terreno da análise histórico-concreta ou da pesquisa histórico-empírica, empreendimento que teria sido realizado pelos autores por mim questionados. ${ }^{4}$ Em seu texto, ele afirma que

[...] o ponto crucial a ser debatido é a passagem da compreensão imanente do trabalho, da classe proletária e do sujeito revolucionário, para a análise ou julgamento de trabalhos que se centram, há décadas, em desenvolver pesquisa histórico-empirica [grifo meu] e que pensam com Marx para além de Marx. (Frigotto, 2009, p. 171, grifos do original)

Ao referir-se diretamente a meu artigo, Frigotto é mais contundente: "a exposição de Tumolo, neste texto, é um exemplo da discussão antinômica, posto por Jameson, e das implicações da passagem de um estudo imanente e heurístico

4 Voltarei a essa questão mais adiante. 
para análise bistórico-concreta" (idem, p. 189, grifo meu). Vejamos em que medida tal argumentação pode sustentar-se.

Uma leitura atenta de meu texto pode demonstrar, claramente, que toda a construção argumentativa está muito colada na tessitura teórica produzida por Marx principalmente em O Capital. $\mathrm{Na}$ verdade, meu artigo não apresenta nada de novo em relação à contribuição marxiana. $\mathrm{O}$ que procuro fazer é apenas reproduzir, de maneira sucinta, sua construção teórica, com ênfase na compreensão do trabalho na forma social do capital. Ora, em O Capital, Marx não faz uma análise de uma determinada fase capitalista ou de uma formação sócio-histórica específica, ou seja, não estuda, por exemplo, o capitalismo inglês do século XIX. Isso significaria que sua análise carece de historicidade? Obviamente que não. Seu objeto de investigação foi o capital e não um determinado capitalismo de uma determinada época porque ele pretendia, nessa obra, dissecar e desvendar as leis gerais que regem o movimento contraditório do capital, vale dizer, a universalidade do capital. Mesmo quando lança mão de estudos histórico-conjunturais, seu objetivo era o de compreender o movimento das particularidades e, dessa forma, apreender as leis da universalidade. É o caso, por exemplo, dos capítulos XI, XII e XIII do livro I de O Capital, nos quais o autor faz uma análise das diversas fases de desenvolvimento capitalista - da cooperação simples à grande indústria, passando pela manufatura -, descendo a detalhes dos diversos processos de trabalho. Não obstante, seu propósito era o de, por meio desses estudos, apreender os elementos de universalidade, quais sejam, a compreensão da mais-valia relativa e, por conseguinte, o movimento de transição da subsunção formal à subsunção real do trabalho ao capital. Isso significa dizer que o objetivo de Marx era a apreensão do capital como universalidade. Justamente aí se expressa, de maneira contundente, a historicidade da análise marxiana em O Capital.

Seguindo essa mesma linha, a compreensão historicizada do trabalho na forma do capital perpassa toda a discussão apresentada em meu texto. No final do artigo, sinalizando as conclusões, afirmo:

Em O Capital, Marx pretende apreender não o ser social genérico de uma forma social genérica, mas o ser social de uma forma social historicamente determinada, a forma capital. Por isso, todas as categorias analíticas que compõem seu construto teórico, sintetizadas na categoria capital, têm como finalidade apreender este ser histórico-social. [...]

$\mathrm{Na}$ obra O Capital, trabalho jamais é apresentado de forma desistoricizada. Ele aparece como trabalho em geral numa forma social genérica e como trabalho uitil (ou concreto), trabalho abstrato e trabalho produtivo (de capital) na forma social capitalista. (Tumolo, 2005, p. 255, grifos do original)

Como já mencionado, uma vez que meu artigo reproduz a construção teórica que Marx apresenta em O Capital acerca do trabalho na sociabilidade do capital, 
e que tal compreensão historicizada foi totalmente incorporada em meu artigo, parece-me inapropriado afirmar, como fez Frigotto, que minha análise carece de historicidade.

Ainda sobre esse assunto, gostaria de fazer algumas observações. Há muito tempo venho estudando de forma sistemática o tema do trabalho. Fiz pesquisas sobre o modelo japonês e a reestruturação produtiva no Brasil, cujos resultados foram publicados em dois textos (Tumolo, 1997b e 2001, respectivamente) e cujo conteúdo foi reunido de forma ampliada em meu livro (Tumolo, 2002), como parte da análise que fiz do atual padrão de acumulação de capital. Tais investigações, calcadas numa ampla base empírica, me permitiram fazer um desenho das características do trabalho na contemporaneidade. A conclusão que pude extrair é a de que as atuais mudanças que vêm ocorrendo nos processos de trabalho apresentam indícios claros de recrudescimento da degradação do trabalho, como resultado necessário do processo de intensificação da exploração sobre a força de trabalho, que se configura como característica determinante do novo padrão de acumulação de capital.

Dessa forma, essas investigações, de teor histórico-empírico, me forneceriam um material abundante para questionar a proposição do trabalho como princípio educativo em várias formas sociais contemporâneas de manifestação do capital. Por que, então, não utilizei esses estudos como argumentação em meu texto? Porque não queria dar um caráter histórico-conjuntural à discussão, mas, ao contrário, pretendia que tivesse uma dimensão histórico-universal. Ou seja, meu intuito era o de questionar o trabalho como princípio educativo como proposta em relação à (e contra a) ordem do capital, e não em relação a qualquer uma de suas manifestações histórico-conjunturais.

O fato de que, em O Capital, Marx tenha feito uma investigação do capital em sua universalidade, não quer dizer que sua análise não seja fundada na historicidade. Pela mesma razão, o fato de meu artigo, avaliado por Frigotto, abordar o tema do trabalho na forma social do capital na dimensão de sua universalidade, e não descer ao terreno de estudos histórico-empíricos, não significa que minha análise careça de historicidade. Pelo contrário. Uma vez que busquei apreender o significado histórico do trabalho na forma histórico-social do capital, como bistórico-universal, calcado na teoria materialista-histórica de Marx, meu texto só poderia ser expressão dessa historicidade. Confirma-se, assim, a impropriedade da afirmação de Frigotto de que minha análise careceria de historicidade. ${ }^{5}$

5 Creio que vale a pena levantar uma indagação. Não teria Frigotto identificado análise fundada na historicidade com análise de situações histórico-empíricas determinadas, ou seja, de particularidades histórico-concretas? Ora, para o marxismo, a análise no 
Da mesma maneira, não tem sentido o argumento de Frigotto de que em minha análise "o capital se torna a categoria antediluviana" (Frigotto, 2009, p. 190) pela mesma razão que a abordagem do capital, em sua universalidade, feita por Marx em O Capital, não converteu o capital numa categoria antediluviana. Ora, para Marx, e também para mim, o capital é uma - e não $a$ - forma histórica de produção da existência humana. Por isso, é produto da ação histórica e sua possível - e, para nós, desejável - superação só pode ocorrer por intermédio de uma intervenção histórica das classes potencialmente revolucionárias.

Antes de dar sequência à discussão, creio que seria necessário fazer um comentário adicional. Como já foi visto, Frigotto argumenta que meu artigo careceria de historicidade e que, portanto, a análise ali contida seria inapropriada para fazer a crítica aos autores que defendem o trabalho como princípio educativo, já que, segundo ele, os trabalhos desses autores "se centram, há décadas, em desenvolver pesquisa histórico-empírica (idem, p. 171, grifo meu), empreendimento que não foi realizado em meu texto. Um exame da produção de tais autores corroboraria essa suposição de Frigotto? Seria verdade que tais autores tomam a defesa do trabalho como princípio educativo fundamentados em pesquisas histórico-empíricas? Parece-me que um exame da produção desses autores referente ao trabalho como princípio educativo conduziria, salvo alguma exceção, a uma resposta negativa, e o próprio artigo de Frigotto é comprovação disso, já que não baseia sua análise em pesquisas histórico-empíricas. ${ }^{6}$

Resta, agora, avaliar o outro aspecto da argumentação de Frigotto: a questão da ausência da contradição em minha análise. É o que discutirei a seguir.

\section{TRABALHO ALIENADO, ANTINOMIA E CONTRADIÇÃO}

Em seu texto, Frigotto afirma que, em meu artigo, busco sustentar a ideia de que

[...] o trabalho, sob o sistema capital, não pode ser entendido e pensado como princípio educativo, isto porque é cada vez mais alienante. Ou seja, o trabalho,

plano da universalidade também é histórica e, portanto, fundada na historicidade. A particularidade somente pode ser entendida como histórica se for particularidade de um universal-histórico. O Capital de Marx buscou desvendar o universal-histórico do capital, e por isso é expressão da mais profunda historicidade. Dessa forma, ambas as análises, no plano do universal-histórico e no plano do particular-histórico, estão fundadas na historicidade.

6 Não cabe, neste artigo, fazer uma explanação detalhada a esse respeito porque não se trata de uma questão crucial. Para uma avaliação pormenorizada, o leitor poderá consultar as próprias fontes. 
nesse caso, seria pura negatividade e por isso impensável como princípio educativo. (idem, ibidem, grifos meus)

Segundo ele, já que meu pressuposto de que o trabalho sob o sistema do capital é trabalho alienado e este é pura negatividade, e como, dessa forma, não considerei a dimensão de positividade do trabalho, então minha análise ficou marcada pela ausência da contradição. Essa é a razão pela qual argumenta que o tratamento analítico que dei em meu texto é antinômico e não dialético. Para explicar melhor a diferença entre antinomia e dialética, o autor lança mão da seguinte citação de Jameson:

$\mathrm{Na}$ antinomia você sabe onde está pisando. Ela afirma duas proposições que efetivamente são radical e absolutamente incompatíveis. É pegar ou largar. Enquanto a contradição é uma questão de parcialidades e aspectos; apenas uma parte dela é incompatível com a proposição que a acompanha. Na verdade ela pode ter mais a ver com forças, ou com o estado das coisas do que com palavras e implicações lógicas [...]. Por sua vez, a antinomia é clara e inequivocamente duas coisas separadas: $\mathrm{x}$ ou $\mathrm{y}$, e isso de forma tal que faz a questão da situação ou do contexto desaparecer por completo. Nossa época é bem mais propícia ao terreno da antinomia do que da contradição. Mesmo no próprio marxismo, terra natal desta última, tendências mais avançadas reclamam da questão da contradição e se aborrecem com ela, como se ela fosse um remanescente do idealismo, capaz de reinfestar o sistema de forma fatalmente antiquada, como os miasmas ou a febre cerebral. (Jameson, 1997, p. 17-18 apud Frigotto, 2009, p. 186)

Parece-me necessário fazer algumas indagações para poder prosseguir com a discussão. Será que Frigotto tem razão em afirmar que meu pressuposto de análise é o trabalho alienado e, por isso, a compreensão do trabalho como pura negatividade? Será que utilizei esse conceito como fundamento para a crítica do trabalho na sociabilidade capitalista e para o questionamento que faço ao trabalho como princípio educativo? Uma leitura de meu texto confirmaria isso? Primeiramente vamos supor que sim.

O trabalho alienado foi um tema que ocupou um posto central e decisivo nos primeiros escritos de Marx e é o conceito-chave de seus Manuscritos econômico-filosóficos (Marx, 2004), convertendo-se numa poderosa arma com a qual o autor-militante fez uma crítica ácida e corrosiva ao capitalismo. De fato, uma leitura cuidadosa desse texto revela que a compreensão que Marx aí apresenta é a de que o trabalho, como trabalho alienado, é pura negatividade. E creio que, na totalidade de sua argumentação, não poderia ser diferente, já que o trabalhador está alienado sob quatro aspectos: em relação ao produto de seu trabalho, no interior de sua própria atividade, no que diz respeito ao outro homem e com relação a si mesmo. Por tudo isso, o trabalhador estaria transformado em mercadoria e, por 
conseguinte, no limite, numa coisa. O trabalho alienado é, portanto, a negação da essência humana.

Se nos Manuscritos econômico-filosóficos Marx defendia que o trabalho se mostrava como pura negatividade, isso quereria dizer que também ele não considerava a contradição? Que ele também fez uma análise antinômica e não dialética? Creio que não. $\mathrm{O}$ movimento do pensamento que Marx expõe nesse texto é profundamente dialético porque é expressão do movimento dialético da própria história. Resumidamente, ele entende que o trabalho, ao longo da história da humanidade, desempenhou o papel de ser o elemento fundante da produção da existência do homem, ou seja, como fator de afirmação da essência humana. Ocorre que, para ele, o advento da propriedade privada altera radicalmente essa condição, porque, junto com ela, surge também o trabalho alienado. Nos Manuscritos econômico-filosóficos, propriedade privada e trabalho alienado mostram-se como os dois lados da mesma moeda. Uma vez que, no capitalismo, a alienação atingiu seu ápice, o trabalho converteu-se no seu contrário, ou seja, o trabalho alienado passa a ser elemento de negação da essência humana. Contudo, a história não para aí. Para que haja a superação dessa condição de negatividade do trabalho, é necessária a superação da propriedade privada, o que somente poderia ocorrer por meio de uma revolução social, que resultaria na negação da condição de negatividade do trabalho e, a partir daí, pela constituição de uma sociedade comunista, a retomada, num patamar superior, do trabalho como afirmação da essência humana. Por isso, um dos temas eleitos pelo autor no texto é o do comunismo. Portanto, ao abordar a totalidade do processo histórico, Marx consegue compreender o trabalho primeiramente como afirmação, depois como negação, em seguida como negação da negação e finalmente como afirmação da essência humana. Indiscutivelmente, uma compreensão profundamente dialética do trabalho.

Se Marx, em seus Manuscritos econômico-filosóficos, valeu-se do trabalho alienado como seu conceito-chave e se ele compreendia que, nessa condição, o trabalho é pura negatividade e se, mesmo assim, ele não pode ser acusado de não levar em conta a contradição e sua análise não pode ser considerada antinômica, então, supondo que eu tenha utilizado em meu texto o conceito de trabalho alienado e, dessa forma, entendido o trabalho como pura negatividade, por que minha análise poderia ser acusada de não considerar a contradição e de ser antinômica? De duas, uma. Ou a análise de Marx não leva em consideração a contradição e, dessa forma, é antinômica, ou minha análise considera a contradição e, portanto, é dialética. Parece, portanto, que a afirmação de Frigotto de que não considerei a contradição e que minha abordagem é antinômica é, no mínimo, problemática.

Contudo, voltemos às indagações levantadas anteriormente. Será que Frigotto tem razão em afirmar que o fundamento de minha análise foi o trabalho alienado e, por isso, o que nela vigorou foi a compreensão de que o trabalho no sistema capitalista é pura negatividade? A resposta só pode ser: não. 
Para começar a demonstração da resposta negativa - apenas a título de curiosidade, porque, a rigor, isso não tem muita importância -, em todo meu texto não aparece uma única vez sequer trabalho alienado, alienação ou, ainda, o trabalho écada vez mais alienante. De forma consciente e deliberada, não utilizei o conceito de trabalho alienado em minha análise e, em nenhum momento, considerei, como afirma Frigotto, que o trabalho é cada vez mais alienante. Por quê? Porque o trabalho alienado é um conceito que Marx lançou mão em seus primeiros estudos e que, como categoria analítica, tem de ser entendido em seu contexto histórico-teórico, o que quer dizer, entre outras coisas, que ele traz consigo a compreensão do trabalho como pura negatividade. Exatamente porque entendo que o trabalho não é pura negatividade, ao contrário do que afirma Frigotto, decidi não utilizar essa ferramenta teórica. Mas isso não é tudo. Vejamos a questão com a cautela que merece.

Há muito tempo venho estudando o tema do trabalho nas obras marxianas, desde aquelas de sua juventude até as do período de sua maturidade. Como parte dos resultados dessa investigação, produzi e publiquei um artigo intitulado "Trabalho, estranhamento e exploração capitalista: dos Manuscritos econômico-filosóficos em direção a O Capital de Marx" (Tumolo, 2006), ${ }^{7}$ no qual faço algumas considerações sobre o tema do trabalho alienado e apresento algumas hipóteses. Nele argumento que os Manuscritos sintetizam o primeiro grande esforço teórico de Marx no qual senta suas bases filosófico-conceituais e que, por isso mesmo, são a expressão de uma incursão primeira em seu itinerário teórico, apresentando potencialidades e, ao mesmo tempo, limites, que serão superados em obras posteriores, sobretudo em O Capital.

Um dos aspectos que destaco neste artigo é o entendimento que Marx tem, nos Manuscritos, do trabalhador como mercadoria. Parece-me que tal compreensão é decisiva e ajuda a entender o trabalho como negatividade da essência humana, uma vez que, sendo mercadoria, o trabalhador seria transformado numa "coisa", porque estaria alienado de tudo, inclusive dele mesmo. Dessa forma, minha suposição é a de que o argumento do trabalho como pura negatividade está diretamente relacionado com a compreensão do trabalhador como mercadoria.

No entanto, 23 anos separam os Manuscritos e a publicação do Livro I de $O$ Capital. Nesse período, Marx, entre outras coisas, mergulhou profundamente em seus estudos referentes à crítica da economia política, que resultaram na produção de milhares de páginas em vários textos, e que encontraram sua forma mais sistemática e acabada em O Capital. É de supor, portanto, que ele tenha dado saltos de qualidade no que tange à apreensão do capital e que sua compreensão teórica em O Capital seja muito mais elaborada e aprofundada. ${ }^{8}$

7 Esse texto foi apresentado, com outro título, numa das sessões do GT Trabalho e Educação, durante a realização da 27a Reunião anual da ANPEd em 2004.

8 Creio que seja necessário fazer um esclarecimento: não partilho da posição segundo a qual haveria uma "cisão" entre o "jovem Marx" e o "velho Marx”. Sua produção teórica 
Diferentemente do que está posto nos Manuscritos, em O Capital Marx entende a força de trabalho como mercadoria e não o trabalhador como mercadoria. Para que a força de trabalho se converta em mercadoria, o trabalhador tem de ser livre e proprietário de sua força de trabalho, ou seja, o trabalhador não pode ser mercadoria. Embora seja uma distinção sutil, não se trata de uma simples diferença. Ela é crucial e decisiva para a compreensão do capital, do ser social que produz sua vida nesta sociabilidade e também, por conseguinte, do trabalho determinado por esta forma social.

Como seria impossível tratar, aqui, de todas as implicações correspondentes às diferenças de compreensão entre O Capital e os Manuscritos, vou deter-me na questão do trabalho. A esse respeito, minha hipótese é a de que, se a ideia da pura negatividade do trabalho está vinculada à suposição de que o trabalhador é mercadoria, conforme estaria entendido nos Manuscritos, o trabalho compreendido com base na condição do trabalhador que vende sua força de trabalho, de acordo com o que aparece em O Capital, expressaria a articulação entre negatividade e positividade, já que o trabalhador não é transformado numa mercadoria, numa "coisa", e, portanto, sua essência humana não seria de todo negada.

Essa suposição persegue-me faz algum tempo e ela impeliu-me a buscar compreender o tema do trabalho nas obras maduras de Marx, não porque desconsidere a importância de sua discussão nos Manuscritos, principalmente a referente ao trabalho alienado, mas sim porque ele oferece nos escritos posteriores um arsenal teórico-político mais elaborado, aprofundado e poderoso para a apreensão e a crítica do capital e, por desdobramento, do trabalho nesta forma social. Foi por essa razão que, propositalmente, não lancei mão, em meu artigo, do conceito de trabalho alienado, uma vez que ele pressupõe o entendimento do trabalho como pura negatividade e isso me soava insuficiente para a compreensão do trabalho em seu mais alto grau de complexidade na forma capitalista.

Essas informações preliminares já fornecem elementos claros para a demonstração do equívoco da afirmação de Frigotto de que minha análise não teria considerado a contradição porque teria se baseado no trabalho alienado e, por isso, no entendimento de que o trabalho seria pura negação. Contudo, penso que devemos dar sequência à discussão.

Uma vez que não me sentia totalmente satisfeito com a contribuição que Marx oferecia nos Manuscritos, ou seja, com a compreensão do trabalho como pura negatividade a partir do fundamento do trabalho alienado, coloquei-me como desafio procurar entender o trabalho no interior da forma capitalista como expressão de sua dupla dimensão contraditória, positividade e negatividade, a partir do estudo de suas obras de maturidade, com destaque para O Capital.

materializada em O Capital é continuação, em outro patamar, de sua produção iniciada nos Manuscritos e não uma ruptura. 
O primeiro resultado desses estudos foi a produção e publicação do artigo intitulado "Trabalho: categoria sociológica chave e/ou princípio educativo? O trabalho como princípio educativo diante da crise da sociedade do trabalho" (Tumolo, 1996). Baseado na compreensão de que o trabalho na forma social do capital não é nem pura negatividade, nem pura "afirmatividade", mas também não é a junção dos dois - negação $e$ afirmação -, como deixam a entender alguns dos defensores do trabalho como princípio educativo, ${ }^{9}$ tentei explicar esse duplo sentido do trabalho por meio das contradições entre as três formas em que aparece o trabalho no capitalismo: trabalho concreto, trabalho abstrato e trabalho produtivo de capital. Contudo, com o passar do tempo foi-me ficando mais evidente que essas três formas constituem uma unidade contraditória do trabalho no modo capitalista de produção e que, por isso, sua apreensão era muito mais complexa. Insatisfeito, portanto, com o patamar explicativo que até então havia conseguido atingir, dei continuidade a meus estudos, e um de seus resultados foi a elaboração e publicação, alguns anos mais tarde, do texto que foi alvo da apreciação crítica de Frigotto.

Apesar de que tivesse apresentado, no primeiro artigo (Tumolo, 1996), uma abordagem claramente contraditória do trabalho no interior do sistema capitalista, concluí que era necessário, no segundo texto (Tumolo, 2003a e 200510), dar um tratamento mais aprofundado e complexificado à questão do trabalho como contradição. Esse foi meu objetivo central nesse último artigo: buscar desvendar e explicar o trabalho como materialização de um complexo de contradições em seu mais alto grau de complexidade, já que é trabalho na forma social do capital, que não é outra coisa senão contradição em processo, tendo como fundamento a contribuição marxiana oferecida em O Capital.

Embora não seja conveniente reproduzir, aqui, toda a análise que empreendi em meu último artigo, avaliado por Frigotto, porque isso implicaria reproduzir o próprio texto, parece-me necessário relembrar alguns aspectos. Começo discutindo o valor de uso, o valor de troca e o valor, a contradição entre valor de troca e valor de uso e, principalmente, a contradição entre valor de uso e valor, que significa a contradição entre trabalho concreto e trabalho abstrato. Dessa forma, explicito meu entendimento da mercadoria - ponto de partida para a compreensão do capital - como unidade contraditória do valor e do valor de uso e, por isso, do trabalho concreto e do trabalho abstrato. Na sequência, introduzo a discussão sobre o capital - já que este pressupõe a mercadoria mas não se esgota nela -, apresentando a fórmula primeira do capital (D-M-D'), ${ }^{11}$ e, por conseguinte, a mais-valia e o conceito de trabalho produtivo de capital. Em seguida, busco demonstrar que a relação entre trabalho concreto, trabalho

9 Vide, por exemplo, Franco (1989).

10 Como já foi mencionado, esse texto teve duas versões.

11 Dinheiro-Mercadoria-Dinheiro acrescido de mais-valia. 
abstrato e trabalho produtivo de capital forma uma unidade contraditória, a partir da compreensão de algumas contradições do movimento do capital, que podem ser sintetizadas na "[...] contradição imanente e inexterminável [...] entre a valorização do valor, o capital, e o valor de uso, a riqueza; entre o trabalho produtivo de capital e o trabalho concreto; entre o capital e a satisfação das necessidades humanas; entre o capital hominizado e o ser social reificado; em suma, entre o capital e a humanidade" (Tumolo, 2005, p. 254, grifos do original).

Com base nesses elementos fundamentais da construção teórica apresentada por Marx em O Capital, argumento, sucintamente, que o trabalho, na sociabilidade capitalista, é a unidade contraditória dos dois sentidos, ou seja, a negação é, contraditoriamente, a afirmação e a afirmação é, contraditoriamente, a negação. Na mesma medida em que o trabalho, na forma capitalista, afirma o ser social, produzindo sua emancipação, o nega, ao produzir sua degradação. De forma sintética, assim me manifesto no artigo:

Portanto, se o trabalho, numa forma social genérica, é "um processo entre o homem e a Natureza, um processo em que o homem, por sua própria ação, media, regula e controla seu metabolismo com a Natureza" (Marx, 1983, p. 149), ou seja, é o elemento determinante na constituição da própria natureza humana, no capitalismo a construção do gênero humano, por intermédio do trabalho, se dá pela sua destruição, sua emancipação se efetiva pela sua degradação, sua liberdade ocorre pela sua escravidão, a produção de sua vida se realiza pela produção de sua morte. Na forma social do capital, a construção do ser humano, por meio do trabalho, se processa pela sua niilização, a afirmação de sua condição de sujeito se realiza pela negação desta mesma condição, sua hominização se produz pela produção de sua reificação. (idem, p. 254-255, grifo do original)

Quase no final dessa citação, inseri uma nota de rodapé em que afirmo: "em contrapartida, supõe-se, em suma, que a produção de sua morte possibilita a produção de sua vida" (idem, p. 260). Em seguida, confirmo, de maneira incontestável, minha compreensão do trabalho como contradição, ao afirmar que " $n$ a forma social do capital, a dimensão de positividade do trabalho se constitui pela dimensão de sua negatividade ${ }^{12}$, seu estatuto de ser criador da vida humana se constrói por meio de sua condição de ser produtor da morte humana" (idem, p. 256, grifo do original). ${ }^{13}$

12 Nesse momento do texto, insiro uma nota de rodapé com os seguintes termos: "neste sentido, me parece insuficiente certo tipo de abordagem que menciona estas duas dimensões do trabalho, positividade e negatividade, sem compreendê-las como componentes de uma relação de contradição. Neste caso, tratar-se-ia muito mais dos dois polos da mesma contradição do que de duas dimensões" (Tumolo, 2005, p. 261).

13 Toda a argumentação e todas essas citações da segunda versão de meu texto estão presentes, ipsis litteris, na primeira versão, que foi utilizada por Frigotto. 
Como se pode perceber claramente, seja pela retomada de alguns aspectos abordados em meu artigo, seja principalmente pela leitura dele, toda minha análise trata o trabalho na forma social do capital como unidade contraditória entre negatividade e positividade, vale dizer, como a mais pura expressão da contradição, porque meu objetivo era apreender o trabalho como contradição, fundado em $O$ Capital, de Marx, que, obviamente, também compreendia o trabalho como contradição. Ademais, se, em minha análise, estou considerando o trabalho como trabalho produtivo de capital, este pressupõe, necessariamente, o trabalho concreto ou útil, produtor de valores de uso, que expressa a dimensão de positividade do trabalho, o que comprova que é totalmente descabida a afirmação de Frigotto de que não considerei a dimensão de positividade do trabalho, já que é impossível a existência do trabalho produtivo de capital sem que haja trabalho útil. Dessa maneira, confirma-se o equívoco de sua afirmação de que o pressuposto de minha argumentação seria a compreensão do trabalho como pura negatividade, e também, por desdobramento, o equívoco de seu argumento de que minha análise teria um caráter antinômico, porque não teria considerado a contradição do trabalho.

Portanto, meus questionamentos ao trabalho como princípio educativo como proposta emancipatória de educação não têm como base a compreensão do trabalho como pura negatividade, mas sim, ao contrário do que afirma Frigotto, o entendimento do trabalho como unidade contraditória de positividade e negatividade. Além disso, parece-me necessário, ainda, prestar um esclarecimento adicional. Em meu artigo, não questionei o trabalho como princípio educativo. Para que não pairem dúvidas a esse respeito, estou totalmente de acordo com o fato de que o trabalho seja ou possa ser princípio educativo. Nas duas versões de meu artigo, meu questionamento é muito diferente, qual seja, a possibilidade de o trabalho, tal como se constitui na sociabilidade capitalista, ser princípio educativo de uma estratégia político-educativa que tenha como horizonte a transformação revolucionária da ordem do capital ${ }^{14}$ (cf. Tumolo, 2003a, p. 10 e 2005, p. 256). Mais tarde, voltarei a essa questão.

Como se viu anteriormente, a crítica central que Frigotto fez a meu texto é a de que haveria, nele, uma ausência de historicidade, basicamente porque, segundo o autor, minha análise não teria considerado a contradição e, como teria se circunscrito à leitura (imanente) de $O$ Capital, não teria descido ao terreno da pesquisa histórico-empírica. Neste segmento, demonstrei o equívoco do primeiro argumento e no segmento anterior comprovei o equívoco concernente ao segundo. Portanto, ao longo da análise desenvolvida neste texto, ficou claramente demonstrada a impropriedade dos dois grandes argumentos de Frigotto e, por

14 A citação que contém essa explicitação está reproduzida no artigo de Frigotto (cf. Frigotto, 2009, p. 188). 
conseguinte, a improcedência de sua afirmação de que minha análise careceria de historicidade.

A discussão realizada até aqui permite extrair a seguinte conclusão: uma vez que todas as críticas que Frigotto desfechou contra meu artigo são improcedentes ou inapropriadas, conforme procurei demonstrar neste texto, então a argumentação ali contida permanece de pé, profundamente sustentada, e, como consequência, os questionamentos que fiz à possibilidade de o trabalho, de acordo com sua natureza na forma social do capital, ser princípio educativo de uma proposta revolucionária de educação continuam tendo plena validade. ${ }^{15}$

\section{O TRABALHO COMO PRINCÍPIO EDUCATIVO NA FORMA SOCIAL DO CAPITAL: A PERSISTÊNCIA DOS QUESTIONAMENTOS}

Uma vez realizada a crítica das críticas feitas por Frigotto a meu texto, creio que seria pertinente, a partir deste momento, tecer algumas apreciações a respeito da questão do trabalho como princípio educativo tal como aparece em Frigotto e, a partir daí, fazer um cotejamento com Saviani e, eventualmente, com outros autores que abordaram tal tema. Para tanto tomarei como referência o texto de Frigotto no qual explicita sua compreensão.

Da leitura que faço do trabalho como princípio educativo em Marx, ele não está ligado diretamente a método pedagógico nem à escola, mas a um processo de socialização e de internalização de caráter e personalidade solidários, fundamental no processo de superação [grifo do original] do sistema do capital e da ideologia das sociedades de classe que cindem o gênero humano. Não se trata de uma solidariedade psicologizante ou moralizante. Ao contrário, ela se fundamenta no fato de que todo ser humano, como ser da natureza, tem o imperativo de, pelo trabalho, buscar os meios de sua reprodução - primeiramente biológica, e na base desse imperativo da necessidade criar $[$ sic $]$ e dilatar o mundo efetivamente livre. Socializar ou educar-se de que o trabalho que produz valores de uso [grifo meu] é tarefa de todos, é uma perspectiva constituinte da sociedade sem classes.

Por ser o trabalho (mediação de primeira ordem) o que possibilita que o ser humano produza-se e reproduza-se, e por isso, na metáfora de Marx, antediluviano [grifo do original], e não o trabalho escravo, servil e o trabalho alienado

$15 \mathrm{Se}$ as críticas feitas por Frigotto a meu texto se mostraram improcedentes, então me parece que seria possível levantar a hipótese de que algo similar poderia ter ocorrido com relação às críticas que fez ao livro de Lessa. Embora eu tenha divergências de fundo com respeito a muitos dos aspectos da argumentação de Lessa, não posso deixar de reconhecer sua importante contribuição para as discussões do tema do trabalho, inclusive em sua relação com a educação. Por esses motivos, creio que seria necessário uma revisita a seu livro e um reexame de sua argumentação. 
sob o capital (mediações de segunda ordem), a internalização, desde a infância, do princípio do trabalho produtor de valores de uso é fundamental [grifo meu]. É dentro desse contexto que entendo a expressão "mamíferos de luxo", de Gramsci, para significar formação e socialização que aliena a possibilidade de perceber que tudo que é produzido para o ser humano produzir a si mesmo como ser da natureza vem do trabalho.

É dessa perspectiva que Marx entende, na minha leitura, a união de trabalho e ensino desde a infância e, ao mesmo tempo, a luta contra a exploração do trabalho infantil. (Frigotto, 2009, p. 189)

Tendo como base essa citação, buscarei fazer uma avaliação de quatro aspectos e levantar algumas questões complementares em relação àquelas já feitas em meu texto (Tumolo, 2005), as quais, como já visto, permanecem válidas.

O primeiro ponto refere-se a seu entendimento de que o trabalho tido como princípio educativo é o trabalho produtor de valores de uso, compreensão idêntica à de Saviani e dos outros autores. A esse respeito, poderiam ser feitas algumas ponderações. Primeiramente, como o próprio autor afirma, o trabalho em sua dimensão ontocriativa, como trabalho em geral, que resulta na produção de valores de uso, que constituem o conteúdo material da riqueza, para satisfazer necessidades humanas - do estômago à fantasia -, é a mediação de primeira ordem, quer dizer, é o elemento fundante na produção da existência do ser social e, por essa razão, foi o fator determinante que propiciou o salto ontológico de um determinado ser orgânico (animal) ao ser social. Sabemos que Marx, Engels e Lukács, apenas para citar os mais importantes, examinaram exaustivamente essa dimensão ontológica do trabalho, ou, se se quiser, esse caráter de positividade do trabalho. Justamente aí se localiza a questão que quis destacar em meu artigo.

O trabalho como produtor de valores de uso, embora necessário, é insuficiente para a compreensão da natureza histórica que o trabalho adquire na forma capitalista. Marx já havia, sistematicamente, alertado para esse problema. No início do capítulo V do Livro I de O Capital, ele apresenta sua magistral e sintética definição de trabalho em geral, produtor de valores de uso - creio ser desnecessário reproduzi-la aqui, porque é deveras conhecida -, e, na primeira parte desse mesmo capítulo, desenvolve sua análise acerca dessa temática. Algumas páginas depois daquela em que expõe a conhecida definição, Marx, com o propósito de fazer as devidas amarrações, descreve a compreensão do processo de trabalho nos seguintes termos: "considerando-se o processo inteiro do ponto de vista de seu resultado, do produto, aparecem ambos, meio e objeto de trabalho, como meios de produção, e o trabalho mesmo como trabalho produtivo" (Marx, 1983a, p. 151). Já que, nessa frase, o autor está referindo-se a trabalho produtivo de valores de uso, no final dela insere uma nota de rodapé decisivamente esclarecedora: "essa determinação de trabalho produtivo, tal como resulta do ponto de 
vista do processo simples de trabalho, não basta, de modo algum, para o processo de produção capitalista" (idem, ibidem, grifo meu).

Mais claro, impossível. A compreensão do trabalho em geral, produtor de valores de uso, é insuficiente para a apreensão do trabalho na forma especificamente capitalista. Por essa razão é que, depois de dar sequência ao exame do trabalho dentro do processo de produção capitalista, ele retoma essa discussão, de forma conclusiva, no capítulo XIV do Livro I. Nesse capítulo, ele começa afirmando que "o processo de trabalho foi considerado primeiramente em abstrato (ver capítulo $\mathrm{V}$ ), independentemente de suas formas históricas, como processo entre o homem e a Natureza" (Marx, 1984, p. 105), e reproduz aquele parágrafo do capítulo V, bem como a nota de rodapé a ele anexada, relembrando o sentido ali conferido ao trabalho produtivo. Se lá tal conceito fora entendido a partir do processo simples de trabalho, como criador de valores de uso, considerando apenas sua dimensão de positividade, agora se trata de compreendê-lo do ponto de vista do processo de produção capitalista, ou seja, como trabalho produtivo de capital. Aqui o autor sela, portanto, seu entendimento do trabalho como contradição, porque não é outra coisa senão trabalho no e para o capital, que é pura contradição.

Em meu texto, reproduzo essa mesma discussão, valendo-me dos mesmos argumentos, justamente porque queria demonstrar os problemas e insuficiências de se considerar, como fazem Frigotto, Saviani e outros autores, o trabalho produtor de valores de uso como princípio educativo no interior da sociabilidade capitalista.

Por que Marx chama a atenção para a diferença de tratamento acerca do trabalho no início do capítulo $\mathrm{V}$ e no restante de sua obra, principalmente no capítulo XIV? Porque seu objetivo, sobre esse quesito, era apreender o trabalho numa forma social específica, a capitalista. Na chamada perspectiva ontológica do trabalho, está presente apenas sua dimensão de positividade, e não a de negatividade, porque a história ainda não havia reunido as condições para a alteração desse caráter unitário do trabalho. Somente com o surgimento da propriedade privada, da mercadoria e, decisivamente, do capital é que o trabalho passa a se constituir como unidade contraditória de seus dois polos, positividade e negatividade. A partir daí, e sobretudo no capitalismo, o trabalho deixa de ser apenas produtor de valores de uso - embora continue sendo - e passa a ser produtor de mercadorias e, principalmente, de capital, o que lhe imprime, em seu fundamento, a marca indelével da contradição. Isso quer dizer que, na forma social do capital, a condição de contradição do trabalho é ineliminável ou, em outras palavras, não se pode considerar apenas uma de suas dimensões, a de positividade ou de negatividade.

Se Frigotto entende que o trabalho como produtor de valores de uso é o princípio educativo na sociabilidade do capital, está entendendo o trabalho apenas em seu caráter de positividade e não está considerando sua dimensão de negati- 
vidade, ou, o que é pior, não o compreende como contradição ou como unidade contraditória dessas duas dimensões. $\mathrm{O}$ esforço que despendi em meu artigo foi no sentido de, exatamente, tentar demonstrar isso. Faz-se necessário lembrar que os questionamentos que fiz ao trabalho como princípio educativo como proposta emancipatória de educação têm como pressuposto a compreensão do trabalho no capitalismo como unidade contraditória e o meu propósito foi o de evidenciar que os autores que tratam desse tema tomam o trabalho apenas em sua dimensão de positividade, como trabalho produtor de valores de uso. Na verdade, Frigotto e outros autores reconhecem o duplo aspecto do trabalho no capitalismo - de positividade e de negatividade -, mas elegem apenas a dimensão de positividade ao eleger o trabalho produtor de valores de uso como princípio educativo. ${ }^{16}$ Ora, no capitalismo é impossível cindir a unidade contraditória e, dessa maneira, escolher apenas um de seus polos - o da positividade -, porque a unidade contraditória constitui a natureza mesma do trabalho na sociabilidade capitalista. O trabalho como unidade contraditória indissolúvel só pode ser superado no plano da materialidade social, vale dizer, pela superação daquilo que o determina como tal, o capital, e não por meio de um exercício textual ou da vontade ou, ainda, da correlação de forças entre as classes sociais no interior do capitalismo, como parece sugerir Frigotto.

Essa conclusão fornece os elementos necessários para a discussão do segundo aspecto. Para Frigotto, o trabalho como princípio educativo, entendido como produtor apenas de valores de uso, está ligado "a um processo de socialização e de internalização de caráter e personalidade solidários, fundamental no processo de superação do sistema do capital e da ideologia das sociedades de classe que cindem o gênero humano" (Frigotto, 2009, p. 189, grifado no original). ${ }^{17}$

De fato, se estivéssemos tratando de uma sociedade fundada no trabalho como produtor apenas de valores de uso, que é a sociedade comunista - o socialismo seria ainda insuficiente -, então me parece coerente afirmar que o trabalho possa estar na base da internalização de um caráter e personalidade solidários, já que numa sociedade como essa, em que não existiriam propriedade privada, mercado, classes sociais, exploração, estado etc., numa palavra, capital, o trabalho seria dotado apenas de sua dimensão de positividade, ou seja, ele retomaria sua condição histórica de

16 Em outro texto de sua autoria, Frigotto confirma essa compreensão ao argumentar que, "em relação ao trabalho, a luta é afirmá-lo como valor de uso e, desta forma, princípio educativo e criador" (Frigotto, 2002, p. 24, grifos meus). Franco (1989) também adota o mesmo procedimento.

17 O autor não deixa claro se está sugerindo que a internalização de um caráter e personalidade solidários ocorreria por meio da prática mesma do trabalho em sua generalidade, ou se está referindo-se a uma prática isolada de trabalho que produz valores de uso. 
ser o elemento fundante na produção da existência do ser social em sua mais alta plenitude, apenas em sua perspectiva emancipatória.

Contudo, como se viu anteriormente, na sociabilidade capitalista, o trabalho não pode ser considerado produtor apenas de valores de uso e, por isso, não se pode escolher apenas sua dimensão de positividade, já que ele é a unidade contraditória indivisível de positividade e negatividade. Sendo assim, partindo do pressuposto de que "não é a consciência dos homens que determina o seu ser, mas, ao contrário, é o seu ser social que determina sua consciência" (Marx, 1974, p. 136), algumas questões são pertinentes. Como seria possível haver a internalização apenas do aspecto de positividade do trabalho, referente a sua condição de produtor de valores de uso, se o trabalho, em sua materialidade capitalista, é a unidade contraditória das dimensões de positividade e negatividade? Seria possível que o trabalho, na forma social do capital, que gera emancipação gerando degradação e vice-versa, seja o fundamento da internalização de um caráter e personalidade solidários? $\mathrm{O}$ trabalho que produz vida produzindo morte e produz morte produzindo vida seria o terreno propício de onde poderia brotar um caráter e personalidade solidários? $\mathrm{Ou}$, ao contrário, não seria justamente a luta contra o trabalho na forma capitalista que poderia gestar um caráter e personalidade solidários, fundamental no processo de superação do sistema do capital? ${ }^{18}$

Essa condição de o trabalho ser, na sociabilidade capitalista, elemento produtor, ao mesmo tempo e contraditoriamente, de vida e morte pode ser visto, também, a partir de outro ângulo. Jogados à sorte do trabalho no modo capitalista de produção, os trabalhadores não passam de vendedores da força de trabalho. Em O Capital, Marx, com sua perspicaz ironia, apresenta a cena em que se desenrola a exploração capitalista, na qual o trabalhador - "tímido, contrafeito" -, ao vender sua força de trabalho para o capitalista - "sorriso satisfeito" -, leva "sua própria pele ao mercado, e agora não tem mais nada a esperar, exceto o curtume" (Marx, 1983a, p. 145, grifo meu). Ocorre que a exploração capitalista - o curtume - não é uma escolha para o trabalhador, mas, sim, uma falta de opção. Para produzir sua vida, ele precisa comprar os meios de subsistência para satisfazer suas necessidades vitais, do estômago à fantasia, e para comprá-los necessita vender alguma mercadoria, já que ninguém pode comprar se, antes, não vender. Como está privado da propriedade de qualquer meio de produção, ele não tem alternativa senão vender a única mercadoria de que dispõe - sua força de trabalho. Ao vendê-la para o capitalista, este vai consumir seu valor de uso, o que resultará no processo de exploração. A exploração

18 Tais questionamentos continuam tendo validade mesmo se se considera que Frigotto esteja propondo uma prática isolada de trabalho que produz valores de uso, uma vez que qualquer prática isolada de trabalho está determinada pelo trabalho na forma capitalista. 
é, portanto, a condição sine qua non para a produção da vida do trabalhador. Se não consegue vender a força de trabalho e, assim, ser explorado, o trabalhador fica ameaçado de morte.

Entretanto, para conseguir vender sua força de trabalho, o trabalhador precisa concorrer com outro vendedor da mesma mercadoria, ou seja, com outro trabalhador. Como no sistema capitalista, em geral, há mais vendedores de força de trabalho do que compradores, resultando numa enorme população de desempregados - que é uma condição da natureza do capitalismo -, para conseguir vender sua força de trabalho, o trabalhador tem de eliminar seu concorrente, o que acarreta a possibilidade da morte deste último. Um caso ilustrativo pode ser visto no filme $O$ corte, do diretor Costa Gavras, que apresenta, com uma linguagem dura e sarcástica, um engenheiro de uma indústria papeleira que havia contribuído para aumentar a produtividade, mas, em virtude do processo de reestruturação da empresa, é demitido e, como não consegue emprego e sua vida começa a se desmoronar, decide arquitetar e executar um engenhoso plano para matar, literalmente, o executivo da outra empresa papeleira que ocupa um posto similar àquele que ele tinha, e também todos os possíveis concorrentes, para atingir seu objetivo: conseguir vender, outra vez, sua força de trabalho. O mais impressionante, contudo, é que em agosto de 2007, por uma infeliz ironia da história, uma ex-estagiária foi condenada porque encomendou o assassinato de duas colegas em dezembro de 2005 para que pudesse ficar com a vaga delas numa empresa de Cubatão.

Em contrapartida, se o trabalhador consegue vender sua força de trabalho, porque logrou eliminar seus competidores, isso não significa que tenha conquistado uma condição segura e estável como vendedor da força de trabalho. Pelo contrário. Depois de estar "empregado" e para manter-se nessa condição, o trabalhador precisa continuar lutando para não permitir que algum possível concorrente o elimine e tome sua vaga.

Esses exemplos ilustram a condição real do trabalhador no interior do capitalismo. Para poder viver, precisa vender sua força de trabalho e, assim, ser explorado, mas, para poder vender sua força de trabalho, ser explorado e, dessa maneira, viver, necessita "matar" seus competidores. Isso quer dizer que o trabalhador é constrangido a estabelecer uma verdadeira guerra de vida e morte com outro trabalhador. Como se não bastasse, é uma luta de vida e morte para conseguir ser explorado. Tal situação repõe as perguntas que foram levantadas anteriormente: que tipo de personalidade pode emergir dessa condição de realidade? Uma personalidade solidária? ${ }^{19}$ Não seria, ao contrário, a luta contra o trabalho na forma do capital que

19 O filme $O$ corte, já mencionado, oferece uma boa contribuição para a discussão dessa questão. Em vários momentos, o personagem principal tem "crises de consciência" por 
poderia gerar um sentimento de solidariedade, na medida em que seu horizonte é a superação não somente da exploração, mas também da concorrência entre os trabalhadores e, por isso, do macabro jogo de vida e morte?

Deixemos que a história e a análise dela nos dê algumas pistas para a discussão dessas questões. Engels, a partir de seu genial opúsculo sobre as condições da classe operária na Inglaterra, Marx, com sua enorme e indiscutível contribuição e até Gramsci em seu ensaio sobre americanismo e fordismo, mas também Braverman com seu magistral estudo sobre o taylorismo-fordismo - apenas para citar os pensadores mais clássicos - e vários autores contemporâneos que vêm analisando as atuais configurações do capitalismo a partir de uma perspectiva materialista-histórica, têm demonstrado, com abundância de dados empíricos, que, desde o surgimento e consolidação do modo capitalista de produção, o trabalho tem gerado um processo de contínua degradação humana. ${ }^{20} \mathrm{Em}$ contrapartida, parece-me que a luta que a classe trabalhadora foi desenvolvendo ao longo de sua história, desde as formas mais rudimentares, como os luddistas no século XVIII, até as formas mais totalizantes, como a realização das revoluções proletárias no século XX, produziu o terreno fértil para o florescimento não apenas de um caráter e personalidade solidários dos trabalhadores, mas, mais que isso, da própria consciência de classe, no movimento contraditório entre classe-em-si e classe-para-si, elemento imprescindível para o processo de superação do sistema capitalista. Se isso é verdade, não seria mais adequado ponderar que é a luta contra o trabalho na sociabilidade do capital que poderia gerar um caráter e personalidade solidários numa perspectiva de classe $\mathrm{e}$ que, portanto, do ponto de vista dos interesses históricos dos trabalhadores, a luta contra o trabalho (na forma capitalista), e não o trabalbo, deveria ser considerada $o$ princípio educativo? ${ }^{21}$

Estas reflexões permitiriam rascunhar a seguinte hipótese: da perspectiva da classe trabalhadora, não é o trabalho que poderia produzir um "processo de socialização e de internalização de um caráter e personalidade solidários, fundamental no processo de superação do sistema capital, da ideologia das sociedades de

estar matando seus concorrentes - com os quais se identifica, já que se encontram na mesma situação precarizada de vida, inclusive desempregados, e, por isso, gostaria de solidarizar-se com eles -, mas, em seguida, recobra a "razão" e "friamente" segue seu mortífero plano, porque sabe, ou melhor, tem "consciência" de que essa é a única alternativa que lhe restou para conseguir vender sua força de trabalho - um emprego - e, dessa maneira, continuar produzindo sua vida.

20 Essa é uma forma "resumida" de compreender o trabalho na sociabilidade capitalista, já que, como se viu no decorrer deste texto, tal compreensão é muito mais complexa.

$21 \mathrm{Na}$ finalização da segunda versão de meu artigo encontra-se a seguinte pergunta: "o princípio educativo não deveria ser [...] a critica radical do trabalho, que implicaria a critica radical do capital e do capitalismo? (Tumolo, 2005, p. 256, grifos do original). 
classe, que cindem o gênero humano" (Frigotto, 2009, p. 189, grifo do original), conforme reivindica Frigotto, e sim a luta contra o trabalbo na sociabilidade do capital; não uma luta contra o trabalho, mas contra o trabalho na forma capitalista. Mas isso implicaria uma luta contra o próprio sistema sócio-metabólico do capital, tema que será tratado adiante.

O terceiro ponto a ser apreciado refere-se a uma discrepância que existe entre os autores quanto ao entendimento do que seja princípio educativo do trabalho. Tomemos alguns deles como exemplo. Como se viu, Frigotto afirma que, da leitura que faz do "trabalho como princípio educativo em Marx, ele não está ligado diretamente a método pedagógico nem à escola" (idem, ibidem, grifo meu). Baseado no mesmo autor, Nosella tem uma posição oposta a essa. Para ele, "Marx introduziu e consagrou, na ciência pedagógica, a ideia de ser o trabalho o elemento determinante e fundamental de todo o processo educativo, logo, de toda instituição escolar" (Nosella, 2009, p. 43, grifo meu). O próprio Frigotto, na nota de rodapé n. 29, afirma que "Manacorda mostra uma ênfase específica de Gramsci, com base em Marx, ao colocar 'o conceito e o fato' do trabalho como 'princípio imanente da escola elementar'" (Frigotto, 2009, p. 189, grifo meu). Saviani corrobora essa mesma posição: “[...] o trabalho foi, é e continuará sendo o princípio educativo do sistema de ensino em seu conjunto. Determinou o seu surgimento sobre a base da escola primária, o seu desenvolvimento e diversificação e tende a determinar, no contexto das tecnologias avançadas, a sua unificação" (Saviani, 1994, p. 161, grifo meu).

Como se pode constatar, não apenas o trabalho é um "termo" polissêmico, de acordo com os argumentos de Frigotto, mas também o princípio educativo do trabalho. Parece que os diferentes significados que os autores mencionados atribuíram a esse tema poderiam ser localizados nas distintas compreensões expressas, de um lado, por Frigotto a partir da ideia de internalização e, de outro lado, pelos outros autores que o relacionam com a configuração e a estruturação do sistema escolar, com destaque para a escola elementar.

O quarto aspecto diz respeito ao fato de que Frigotto, em todo seu texto, não explicita qual é a parte da obra de Marx em que este tenha tratado do trabalho como princípio educativo. Apenas menciona, sem citar as fontes, sua proposta referente à união entre trabalho e ensino. Isto significaria dizer que trabalho como princípio educativo e união de trabalho e ensino são a mesma coisa? Se a resposta é negativa, então não há, no texto de Frigotto, nenhuma explicação do que seja trabalho como princípio educativo em Marx. Se, ao contrário, a resposta é afirmativa, então é possível levantar outras indagações. Ao apresentar a ideia de união entre trabalho e ensino, como proposta no interior da sociabilidade capitalista, a compreensão de trabalho de Marx também é a de trabalho produtor apenas de valores de uso? Tal proposta de Marx - a união de trabalho e ensino - estaria de acordo com a acepção 
apresentada por Frigotto acerca do trabalho como princípio educativo, ou seja, de que ela não está ligada "diretamente a método pedagógico nem à escola" (Frigotto, 2009, p. 189)? Será que Marx entendia que a ideia de união de trabalho e ensino no interior do capitalismo estaria ligada, como argumenta Frigotto, "a um processo de socialização e de internalização de caráter e personalidade solidários, fundamental no processo de superação do sistema do capital e da ideologia das sociedades de classe que cindem o gênero humano" (idem, ibidem, grifo do original)? Creio que tais perguntas, com ênfase para a última, indicam a necessidade de se discutir o caráter dessa proposição pleiteada por Marx, no contexto de suas propostas táticas e estratégicas. Parece-me que essa é a discussão fundamental e, por isso, procurarei abordá-la a seguir.

\section{TRABALHO, EDUCAÇÃO E ESTRATÉGIA PROLETÁRIA}

O tema da educação, inclusive em sua relação com o trabalho, nunca foi tratado pelos autores-militantes de linhagem marxista de forma isolada. Geralmente esse assunto aparece sob dois enfoques, articulados ou não entre si: como objeto de estudos críticos que buscaram desvendar o papel desempenhado pela educação nos diversos modos de produção, com ênfase para o capitalista; e na forma de propostas de educação no interior do capitalismo, como componente de seus respectivos projetos estratégicos. Alguns pensadores o abordam, ainda, sob um terceiro enfoque, oferecendo propostas de educação referentes ao socialismo e/ou ao comunismo, como elemento de contribuição para a construção dessas sociedades. Isso pode ser comprovado nas produções de Marx, Engels, Lenin, Krupskaya, Makarenko, Gramsci, Snyders, Suchodolski, apenas para lembrar os mais conhecidos, e também de autores brasileiros, a começar por Saviani.

Tal procedimento teórico-político, de buscar pensar e discutir a educação dentro do complexo histórico-social no qual ela se insere e se produz e como elemento componente de um projeto político, seja de superação do capitalismo ou de construção do socialismo e do comunismo, implica dois desdobramentos para as questões aqui debatidas.

O primeiro deles refere-se à necessidade de enfatizar-se que discutir o trabalho como principio educativo em si mesmo não tem nenbum sentido. Em geral, os autores marxistas que trataram desse tema o compreenderam como elemento constitutivo de uma proposta de educação, que, por sua vez, fazia parte de uma proposição estratégica. Tradicionalmente, o trabalho foi entendido como princípio educativo dentro da proposta proletária de escola unitária e politécnica, que vem sendo apreciada no âmbito de projetos políticos ao longo da história do movimento da classe trabalhadora, como atesta o estudo feito por Machado (1989). Retirá-lo ou 
deslocá-lo desse contexto significa extrair seu substrato teórico e, sobretudo, político. Creio que esse risco tem sido iminente nos últimos anos e, por essa razão, esvaziado de seu conteúdo original, o trabalho como princípio educativo, em si mesmo, pode servir, como tem acontecido, a vários tipos de interpretação, de acordo com as conveniências e os interesses. Ademais, como já foi visto, se há uma compreensão polissêmica do trabalho e, muito mais ainda, do princípio educativo do trabalho, a combinação de ambos permite uma infinidade de sentidos. Por isso, creio que seja necessário recuperar a tradição da linhagem marxista que ofereceu sua contribuição a respeito dessa temática e retomar a questão da estratégia revolucionária, o papel que nela pode desempenhar a educação e, dessa forma, recuperar o conteúdo e o significado originais do trabalho como princípio educativo.

O segundo desdobramento, continuação do anterior, diz respeito a dois fatores organicamente articulados: a determinação do projeto estratégico em relação às propostas de educação, ou seja, é o primeiro que determina as segundas e não o contrário; e o caráter relativo do projeto estratégico e, por conseguinte, das propostas de educação, o que quer dizer que ambos são sempre relativos a determinadas configurações sócio-históricas. Para melhor entendermos essas questões, tomemos dois exemplos ilustrativos: Marx/Engels e Gramsci.

Marx e Engels, como se sabe, nunca produziram um texto sistemático específico sobre o tema da educação. Tal assunto está presente em vários textos dispersos em diferentes abordagens. Além de alguns capítulos de O Capital, nos quais Marx faz uma avaliação crítica da educação e da escola relacionando-as às questões da infância e do trabalho infantil, as discussões acerca da educação e do ensino aparecem, sobretudo, em textos que tratam de programas ou de projetos de ação política, seja para fazer a crítica a determinadas propostas, seja para apresentar proposições, como é o caso, entre outros, das Instruções para os delegados do Conselho Geral Provisório (Marx, 1983b), escrito em 1866, e da Crítica ao Programa de Gotha (Marx, 1975), redigido em 1875.

Um estudo desses textos pode demonstrar que as propostas de ação tática visavam pressionar os limites do capitalismo tal como estava configurado naquela determinada situação histórica e, por isso, naquela época, tinham uma perspectiva progressista e vanguardista, mas hoje perderam sentido ou se constituem como bandeiras políticas rebaixadas. Nas Instruções para os delegados do Conselho Geral Provisório (Marx, 1983b), por exemplo, Marx propôs oito horas de trabalho como limite legal da jornada de trabalho. $\mathrm{O}$ mesmo caráter tem suas propostas com relação ao trabalho das crianças e dos jovens, bem como aquelas referentes à combinação do trabalho das crianças e dos jovens da classe operária com a educação, entendida como educação mental, física e instrução tecnológica. Todas essas propostas são, portanto, relativas àquelas condições históricas e só têm sentido político no âmbito daquele contexto. Somente dentro dessa compreensão é que podemos entender 
porque Marx propôs, nas mesmas Instruçôes, que qualquer criança deve tornar-se trabalhador produtivo desde os 9 anos de idade. É verdade que ele adicionou algumas condições: que o trabalho de crianças de 9 a 12 anos seja restringido legalmente a duas horas diárias e que haja combinação com a educação. Mesmo assim, hoje, a proposta de trabalho produtivo para crianças de 9 anos soaria como um absurdo, mas, tal como Marx a formulou, era avançada para a época e para aquelas circunstâncias, já que o próprio sistema capitalista havia empurrado as crianças para a realidade do trabalho. ${ }^{22}$ Percebe-se, assim, que as ações táticas propugnadas por Marx, inclusive aquelas referentes à educação, são relativas àquele determinado contexto histórico e não necessariamente teriam validade hodiernamente. Porém, isso não diz respeito somente às ações táticas, mas também aos projetos estratégicos elaborados por Marx e Engels, cujas formulações estão espalhadas por alguns textos produzidos ao longo de suas vidas, como é o caso, por exemplo, da Mensagem do comitê central à liga dos comunistas (Marx \& Engels, s.d.), escrito pelos dois autores em 1850. Uma apreciação desse texto evidencia que, a partir da análise que fizeram daquele determinado contexto histórico, buscaram formular um projeto estratégico revolucionário para a classe proletária, que ficou conhecido como "fórmula da revolução permanente". Por suposto, tal projeto só poderia ser relativo àquela determinada realidade histórica.

O mesmo vale para a inestimável contribuição gramsciana. Dentre os autores marxistas, provavelmente Gramsci tenha sido aquele que mais abordou o tema da cultura e, por decorrência, da educação. Contudo, Gramsci não era um pedagogo nem um cientista da educação. Ele foi, acima de tudo, um grande estrategista, já que buscou compreender os elementos constitutivos fundamentais da realidade capitalista que se configurava no início do século $\mathrm{XX}$, com destaque para o tema do Estado, e, daí, procurou elaborar sua estratégia, que ficou conhecida como "fórmula da hegemonia civil”. É justamente a partir desse ponto de vista que ele trata as questões da cultura e da educação.

Em dois textos de minha autoria (Tumolo, 1991 e 1997a), fiz uma análise de três grandes projetos estratégicos, relacionados a seus respectivos contextos históricos: a "fórmula da revolução permanente" de Marx e Engels, a formulação estratégica referente à Revolução Russa de 1917 e a "fórmula da hegemonia civil" de Gramsci. A conclusão que extraí foi a de que

[...] a formulação estratégica é sempre uma resposta histórica a uma realidade histórica. Por isso, a "fórmula da revolução permanente" foi elaborada como resposta histórica àquela realidade concreta analisada por Marx e Engels, assim

22 Enguita (1993) faz um pertinente estudo a esse respeito. 
como o "modelo Petrogrado", expressão da realização da "fórmula da revolução permanente", foi a resposta histórica (vitoriosa) à realidade russa, da mesma forma que a "fórmula da hegemonia civil" foi elaborada como resposta histórica àquela realidade concreta estudada por Gramsci. (Tumolo, 1997a, p. 96)

Por isso,

[...] a fórmula estratégica a ser utilizada pelo proletariado em sua luta contra a burguesia é relativa a determinadas realidades históricas e, portanto, a determinadas configurações de Estado. A "fórmula da hegemonia civil" preconizada por Gramsci foi "extraída" da análise que ele fez da realidade dos países capitalistas centrais da Europa, ou seja, do "Estado moderno", fruto das transformações ocorridas no próprio capitalismo e que, portanto, só pode ser relativa àquela realidade. (idem, ibidem)

Entretanto, embora os fundamentos universais do capital não tenham se alterado, a realidade do capitalismo hoje é distinta daquela da época de Marx e Engels e de Gramsci, principalmente quando se trata da conformação do capitalismo na periferia do sistema. Isso coloca, portanto, a necessidade de se repensar o projeto estratégico-tático para o proletariado atualmente. Se a "fórmula da revolução permanente" era uma resposta histórica àquela dada realidade histórica analisada por Marx e Engels, sendo a Revolução Russa a expressão de sua realização e ao mesmo tempo de seu esgotamento; e se a "fórmula da hegemonia civil” era, de uma só vez, superação da fórmula anterior e resposta histórica àquela determinada realidade analisada por Gramsci, fruto de modificações ocorridas no próprio capitalismo, então o proletariado, hoje, deve elaborar sua fórmula estratégica como resposta histórica a essa realidade concreta, fruto do desenvolvimento contraditório do capitalismo.

Evidentemente, há elementos universais nas formulações estratégicas proletárias, como, por exemplo, a necessidade de destruição do Estado capitalista por meio de uma revolução violenta com vistas à superação dos elementos que constituem os fundamentos do capitalismo, que é o objetivo de toda estratégia revolucionária, mas as diversas táticas com seus objetivos táticos, que compõem, de maneira articulada, o projeto estratégico são sempre relativos a determinadas configurações sócio-históricas capitalistas.

Se os projetos estratégicos apresentados por Marx e Engels e Gramsci, aí incluídas as ações táticas, foram adequados para as configurações históricas de seus respectivos tempos, sua validade política para a realidade contemporânea fica questionada. Isso implica que as propostas de educação e ensino apresentadas por eles também devem ser questionadas, já que eram derivadas e compunham o núcleo de suas formulações estratégicas. 
Se é verdade, portanto, que propostas concernentes à educação e à escola que atendam aos interesses dos trabalhadores estão relacionadas com o projeto estratégico do proletariado, e este só pode ser uma resposta histórica a uma realidade concreta, então temos de admitir que, atualmente, tais propostas não podem ser pensadas tendo como modelo as proposições de Marx e Engels e de Gramsci, mas têm de ser discutidas no contexto da realidade contemporânea, articuladas com o projeto de transformação revolucionária desta determinada realidade.

Isso não significa dizer que não podemos aproveitar e incorporar as contribuições acerca da educação e da escola oferecidas por esses autores e por outros pensadores marxistas. Contudo, o caminho a seguir deve ser o mesmo trilhado por eles e pelos grandes autores-militantes de linhagem marxista, qual seja, o de, primeiramente, fazer uma análise da realidade capitalista que se pretende transformar, baseada no exercício do método materialista dialético e na contribuição teórica que buscou desvendar as leis que regem o movimento contraditório do capital, para, a partir daí, debater e construir a formulação estratégica mais adequada, composta de suas ações táticas e, finalmente, discutir, nesse âmbito, as questões relacionadas à educação e à escola. Se as propostas daqueles autores acerca dessa temática estiverem adequadas a esse projeto estratégico, obviamente, deveriam ser incorporadas. Do contrário, não me parece cabível sua incorporação. Isso quer dizer que a direção a ser seguida é a do projeto estratégico para as propostas de educação e escola e não o inverso. Esse parece ser o grande desafio que se põe para os marxistas atualmente, inclusive para aqueles que estão inseridos no campo da educação.

Com este texto, procurei oferecer uma pequena contribuição e não tive, nem de longe, a intenção de esgotar o debate acerca do trabalho como princípio educativo e muito menos o correspondente à formulação estratégica proletária hodierna, já que considero que se trata de duas discussões inesgotáveis, o que exige, portanto, um processo de continuidade. Contudo, sugiro que, no prosseguimento do debate, o foco da análise não seja o trabalho como princípio educativo, pelas razões aqui expostas, e sim a discussão do projeto estratégico de caráter proletário, baseado na análise da realidade capitalista contemporânea, e o papel, as potencialidades e os limites da educação, escolar ou não, dentro desse projeto, com vistas à superação revolucionária do sistema sócio-metabólico do capital.

\section{REFERÊNCIAS}

Engels, Friedrich. Do socialismo utópico ao socialismo cientifico. São Paulo: Global, 1988. Enguita, Mariano Fernández. Trabalho, escola e ideologia. Marx e a crítica da educação. Porto Alegre: Artes Médicas, 1993. 
Franco, Maria Laura P. Barbosa. Possibilidades e limites do trabalho enquanto princípio educativo. Cadernos de Pesquisa, São Paulo: Fundação Carlos Chagas, n. 68, p. 29-38, 1989. FrigotTo, Gaudêncio. A dupla face do trabalho: criação e destruição da vida. In: ___ Ciavatta, Maria. (Org.) A experiência do trabalho e a educação básica. Rio de Janeiro: DP\&A, 2002.

. Fundamentos científicos e tecnológicos da relação trabalho e educação no Brasil de hoje. In: Lima, Júlio C. F.; Neves, Lúcia M.W. (Org.). Fundamentos da educação escolar do Brasil contemporâneo. Rio de Janeiro: Fiocruz, 2006.

A polissemia da categoria trabalho e a batalha das ideias nas sociedades de classe. Revista Brasileira de Educação, v. 14, n. 40, Campinas: Autores Associados, 2009. Gramsci, Antonio. Os intelectuais e a organização da cultura. Rio de Janeiro: Civilização Brasileira, 1985.

LENIN, Vladimir Ilitch. Sobre as tarefas do proletariado na presente revolução (Teses de abril). In: Lenine, Vladimir Ilitch. Obras escolhidas. São Paulo: Alfa-Omega, 1982, v. 2. . O Estado e a revolução. São Paulo, Hucitec, 1987.

LEsSA, Sergio. Trabalho e proletariado no capitalismo contemporâneo. São Paulo: Cortez, 2007. Machado, Lucilia R. de Souza. Politecria, escola unitária e trabalho. São Paulo: Cortez; Autores Associados, 1989.

Marx, Karl. Prefácio de Para a crítica da economia politica. In: Manuscritos econômico-filosóficos e outros textos escolbidos. São Paulo: Abril Cultural, 1974 (Os pensadores).

. Crítica ao Programa de Gotha. In: MArx, Karl; Engels, Friedrich. Crítica dos Programas de Gotha e de Erfurt. Santos: Estampa, 1975.

. O Capital. São Paulo: Abril Cultural, 1983a, v. I, 1.

. Instruções para os delegados do Conselho Geral Provisório. As diferentes questões. In: MARX, Karl; Engels, Friedrich. Obras escolbidas. Tradução José Barata-Moura. Lisboa: Editorial Avante!, v. 2. p. 79-88, 1983b, v. I, 2.

. O Capital. São Paulo: Abril Cultural, 1984, v. I, t. 2.

. Salário, preço e lucro. São Paulo: Global, 1988.

. A miséria da filosofia. São Paulo: Global, 1989.

. Manuscritos econômico-filosóficos. São Paulo: Boitempo, 2004.

. As lutas de classe na França de 1848 a 1850. In: MarX, Karl; Engels, Friedrich. Obras escolbidas. São Paulo: Alfa-Omega, v. 1, s.d. 1.

. O Dezoito Brumário de Luiz Bonaparte. In: MARX, Karl; Engels, Friedrich. Obras escolbidas. São Paulo: Alfa-Omega, v. 1, s.d. 2.

. A guerra civil na França. In: MARX, Karl; EngeLs, Friedrich. Obras escolbidas. São Paulo: Alfa-Omega, v. 2, s.d. 3. 
Marx, Karl; Engels, Friedrich. Manifesto do Partido Comunista. São Paulo: Cortez, 1998.

- Mensagem do comitê central à liga dos comunistas. In: Obras escolhidas. São Paulo: Alfa-Omega, v. 1, s.d.

Nosella, Paolo. A construção histórica do trabalho como princípio educativo. In: Menezes Neto, Antônio J. et al. (Org.). Trabalho, política e formação humana: interlocuções com Marx e Gramsci. São Paulo: Xamã, 2009.

Saviani, Dermeval. O nó do ensino de $2^{\circ}$ grau. Bimestre, São Paulo: MEC/INEP; CENAFOR, n. 1, 1986.

. O trabalho como princípio educativo frente às novas tecnologias. In: FERRETTI, Celso João et al. (Org.). Novas tecnologias, trabalho e educação: um debate multidisciplinar. Petrópolis: Vozes, 1994.

. O choque teórico da politecnia. Trabalho, educação e saúde, Rio de Janeiro: Fiocruz, Escola Politécnica de Saúde Joaquim Venâncio, v. 1, n. 1, p. 131-152, 2003. Tumolo, Paulo Sergio. Educação e hegemonia no Brasil. Notas para uma reflexão crítica. São Paulo: PUC, 1991.

. Trabalho: categoria sociológica chave e/ou princípio educativo? $\mathrm{O}$ trabalho como princípio educativo diante da crise da sociedade do trabalho. Perspectiva, Florianópolis: UFSC/CED, n. 26, p. 39-70, 1996.

. Gramsci, a educação e o Brasil. Notas para uma reflexão crítica. Universidade e Sociedade, ano VII, n. 12(91-98), 1997a.

. Metamorfoses no mundo do trabalho: revisão de algumas linhas de análise. Educaşão e Sociedade, Campinas: CEDES, v. 59, p. 333-350, $1997 \mathrm{~b}$.

. Reestruturação produtiva no Brasil: um balanço crítico introdutório da produção bibliográfica. Educação \& Sociedade, Campinas: CEDES, n. 77, p. 71-99, 2001.

. Da contestação à conformação. A formação sindical da CUT e a reestruturação capitalista. Campinas: Editora da UNICAMP, 2002.

. O significado do trabalho no capitalismo e o trabalho como princípio educativo: ensaio de análise crítica. Revista eletrônica Trabalbo Necessário, NEDATE/ UFF, ano 1, n. 1, 2003a.

. Trabalho, vida social e capital na virada do milênio: apontamentos de interpretação. Educação E̋ Sociedade, Campinas: CEDES, n. 82, 2003b.

. O trabalho na forma social do capital e o trabalho como princípio educativo: uma articulação possível? Educação E̊ Sociedade, Campinas: CEDES, v. 26, n. 90, p. 239$-265,2005$.

.Trabalho, estranhamento e exploração capitalista: dos Manuscritos econômico-filosóficos em direção ao Capital de Marx. In: ALves, Giovanni et al (Org.). Trabalho e educação: contradições do capitalismo global. Maringá: Praxis, 2006. 


\section{SOBRE O AUTOR}

Paulo Sergio Tumolo é doutor em educação pela Pontifícia Universidade Católica de São Paulo, com pós-doutorado pela Universitat Autónoma de Barcelona. Professor associado da Universidade Federal de Santa Catarina - Centro de Ciências da Educação, e do Programa de Pós-Graduação em Educação, linha de pesquisa Trabalho e Educação. E-mail: tumolo@ced.ufsc.br 
Trabalho, educação e perspectiva histórica da classe trabalhadora: uma continuação do debate

$\mathrm{O}$ artigo pretende dar prosseguimento ao debate teórico-político em torno do tema do trabalho como princípio educativo estabelecendo uma interlocução privilegiada com o texto de Gaudêncio Frigotto intitulado "A polissemia da categoria trabalho e a batalha das ideias nas sociedades de classe" publicado na Revista Brasileira de Educação n. 40, 2009, no qual o autor faz uma série de considerações críticas a um artigo de Paulo Tumolo publicado originalmente na forma eletrônica em 2003 e posteriormente na bevista Educação E Sociedade n. 90, 2005, com o título 
de "O trabalho na forma social do capital e o trabalho como princípio educativo: uma articulação possível?”. Primeiramente, o presente artigo faz uma avaliação crítica das críticas apresentadas por Frigotto contra o texto de Tumolo, com ênfase em dois conjuntos de questões centrais. A primeira diz respeito à historicidade, à ideia de que devemos "Pensar com Marx para além de Marx", e à questão da práxis política, e a segunda refere-se aos temas da contradição, da antinomia e do trabalho alienado. Finalmente o artigo discute outras questões concernentes à relação entre trabalho, educação e estratégia de superação do capitalismo.

Palavras-chave: trabalho como princípio educativo; capitalismo; classe trabalhadora; perspectiva histórica

\section{Labour, education and historical perspective of the working class: a continuation of the debate}

This article aims at continuing the theoretical and political debate on the theme labour as an educational principle by establishing an interlocution with the text by Gaudêncio Frigotto entitled "A polissemia da categoria trabalho e a batalha das ideias nas sociedades de classe" published in Revista Brasileira de Educação n. 40, 2009, in which the author critiques an article by Paulo Tumolo, originally published as an electronic media in 2003 and, in 2005, published in revista Educação \& Sociedade n. 90, with the title "O trabalho na forma social do capital e o trabalho como principio educativo: uma articulação possivel?". This article presents an appraisal of the critiques by Frigotto addressed to the text by Tumolo, with the focus on two main issues. The first concerns the historicity, the idea that we must "Think with Marx beyond Marx", as well as the political praxis, and the second concerns the issues of contradiction, of antinomy, and of the alienated work. The article also presents other issues concerning the relationship among labour, education, and strategy for surpassing capitalism.

Keywords: labour as an educational principle; capitalism; working class; historical perspective

\section{Trabajo, educación y perspectiva histórica de la clase trabajadora: una continuación del debate}

El presente artículo pretende dar seguimiento al debate teórico y politico en relación al tema del trabajo como principio educativo estableciendo una interlocución privilegiada con el texto de Gaudencio Frigotto titulado "La polisemia de la categoría trabajo y la batalla de las ideas en las sociedades de clase", publicado en la Revista Brasileira de Educação n. 40, de 2009, en la cual el autor realiza una serie de consideraciones críticas a un artículo de Paulo Tumolo publicado originalmente en versión electrónica en el año de 2003 y posteriormente en la revista Educação \& Sociedade n. 90, de 2005, con el titulo "El trabajo en la forma social del capital y el trabajo como principio educativo: una articulación posible?". Primeramente, se realiza, en este artículo, una evaluación crítica de 
las críticas presentadas por Frigotto contra el texto de Tumolo, con énfasis en dos conjuntos de cuestiones centrales. La primera sobre la historicidad, la idea de que debemos "pensar con Marx más allá de Marx" y la cuestión de la praxis politica, y la segunda se refiere a los temas de la contradicción, de la antinomia y del trabajo alienado. Para finalizar, el articulo discute otros aspectos concernientes a la relación entre trabajo, educación y estrategia de superación del capitalismo.

Palabras clave: trabajo como principio educativo; capitalismo; clase trabajadora; perspectiva histórica 